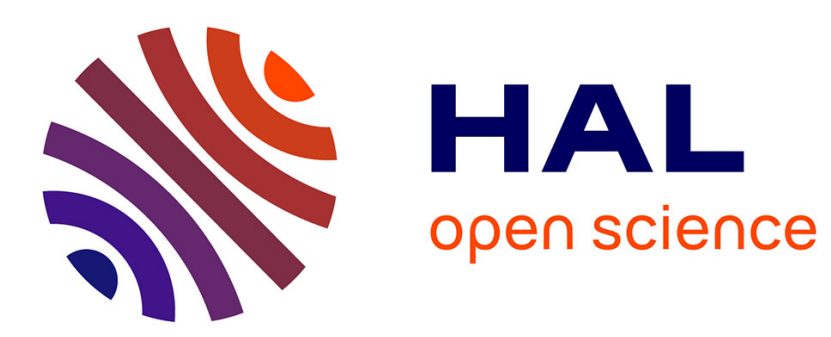

\title{
The prion-like spreading of $\alpha$-synuclein: From in vitro to in vivo models of Parkinson's disease
}

\author{
Jessica Vargas, Clara Grudina, Chiara Zurzolo
}

\section{To cite this version:}

Jessica Vargas, Clara Grudina, Chiara Zurzolo. The prion-like spreading of $\alpha$-synuclein: From in vitro to in vivo models of Parkinson's disease. Ageing Research Reviews - ARR, 2019, 50, pp.89-101. 10.1016/j.arr.2019.01.012 . pasteur-02263600

\section{HAL Id: pasteur-02263600}

\section{https://hal-pasteur.archives-ouvertes.fr/pasteur-02263600}

Submitted on 21 Oct 2021

HAL is a multi-disciplinary open access archive for the deposit and dissemination of scientific research documents, whether they are published or not. The documents may come from teaching and research institutions in France or abroad, or from public or private research centers.
L'archive ouverte pluridisciplinaire HAL, est destinée au dépôt et à la diffusion de documents scientifiques de niveau recherche, publiés ou non, émanant des établissements d'enseignement et de recherche français ou étrangers, des laboratoires publics ou privés.

\section{다)(1) $(5$}

Distributed under a Creative Commons Attribution - NonCommerciall 4.0 International 


\title{
The prion-like spreading of $\alpha$-synuclein: From in vitro to in vivo models of
}

\section{Parkinson's disease.}

\author{
Jessica Y. Vargas ${ }^{1 *}$, Clara Grudina ${ }^{1 *}$ and Chiara Zurzolo ${ }^{1 \#}$ \\ ${ }^{1}$ Unité de Traffic Membranaire et Pathogénèse, Institut Pasteur, Paris, France. \\ * These two authors contributed equally to this work. ${ }^{\#}$ Corresponding author e-mail: \\ chiara.zurzolo@pasteur.fr
}

Abstract

Parkinson's disease (PD) is the second most common neurodegenerative disorder after Alzheimer's disease. PD is characterized by the loss of dopaminergic neurons, primarily in brain regions that control motor functions, thereby leading to motor impairments in the patients. Pathological aggregated forms of the synaptic protein, $\alpha$-synuclein ( $\alpha$-syn), are involved in the generation and progression of PD. In PD brains, $\alpha$ syn accumulates inside neurons and propagates from cell-to-cell in a prion-like manner. In this review, we discuss the in vitro and in vivo models used to study the prion-like properties of $\alpha$-syn and related findings. In particular, we focus on the different mechanisms of $\alpha$-syn spreading, which could be relevant for the development of alternative therapeutic approaches for PD treatment.

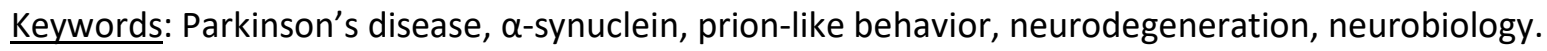


$\underline{\text { Introduction }}$

Parkinson disease (PD) is a neurodegenerative disorder characterized by a progressive loss of motor function in patients that could be accompanied by a wide range of symptoms including cognitive impairment, sleep and mood disorders, gastrointestinal disturbances and autonomic failure (Takamatsu et al., 2018). The hallmark of PD brains is the presence of intraneuronal inclusions called Lewy bodies (LBs) and Lewy neurites (LNs), which are mainly composed of aggregates of $\alpha$-synuclein ( $\alpha$-syn) (Poewe et al., 2017). Point mutations in the gene encoding $\alpha$-syn protein (A30P, E46K, H50Q, G51D, A53E and A53T), as well as genomic duplications or triplications containing the $\alpha$-syn locus, can result in familial forms of PD (Wong and Krainc, 2017). In the sporadic form of PD, aging is considered as a major risk factor. In fact, the incidence of PD significantly increases with age. Epidemiological studies have demonstrated that the risk of PD increases approximately 10-fold between the ages of 50 and 81 (Collier et al., 2017). Moreover, different PD phenotypes and the speed of disease progression could be influenced by the age (Collier et al., 2017). Indeed an analysis on recently diagnosed PD patients reported that the older age of onset is associated with more severe PD-related symptoms and with a disbalance of $\alpha$-syn levels in the cerebrospinal fluid (CSF) (Pagano et al., 2016). However, the age of onset seems to affect the rate of progression at early and middle stages of PD but not at advanced stages (Fereshtehnejad and Postuma, 2017; Kempster et al., 2010).

Interestingly, $\alpha$-syn has an important role in both the generation of PD, and in the progression into more advanced stages of the disease (Del Tredici and Braak, 2016). Postmortem observations of PD brains at different stages of the disease serve as evidence that the spreading of the pathology is correlated with the presence of $\alpha$-syn inclusions in extensive areas of the brain (Braak et al., 2003). Sporadic PD develops and progresses following the spreading of $\alpha$-syn-positive inclusions throughout the brain in a stereotypic manner (Braak et al., 2003), suggesting that $\alpha$-syn can spread from cell to cell in the brain. Similarly to prion and other neurodegenerative diseases, PD can be initiated by toxic, aggregated forms of $\alpha$-syn that are able to induce the conversion of endogenous $\alpha$-syn into the pathological form, which can spread throughout the 
brain, propagating the protein misfolding and the disease (Makin, 2016). For more than a decade, researches have focused on questions like: How $\alpha$-syn aggregates can induce the pathological conformation of the endogenous protein? How can $\alpha$-syn propagate in the brain? Several mechanisms for $\alpha$-syn intercellular spreading have been proposed over the years. However, the exact manner by which $\alpha$-syn transfers from one cell to another is still unclear. Understanding how $\alpha$-syn aggregates and spreads will help develop new therapeutic strategies aimed at slowing or stopping PD progression. Here, we review the most relevant studies demonstrating $\alpha$-syn's prion-like behavior in vivo and in vitro.

\section{1. $\underline{\alpha-S y n}$ and the Prion Hypothesis}

Prion proteins are infectious agents composed of misfolded forms of native cellular protein ( $\left.\operatorname{PrP}{ }^{C}\right)$, called scrapie $\left(\operatorname{PrP}^{\mathrm{Sc}}\right)$. One remarkable feature of $\operatorname{PrP}^{\mathrm{Sc}}$ is its ability to propagate from an infected cell to a healthy one, where it seeds the misfolded conformation on $\mathrm{PrP}^{\mathrm{C}}$, thus generating self-propagating species that can spread throughout the healthy tissue (Prusiner, 1991). Many studies have suggested that other mammalian proteins show a prion-like domain and that protein misfolding is a common feature in most neurodegenerative diseases (Jucker and Walker, 2018). In PD, the pathological form of $\alpha$-syn is structurally similar to $\operatorname{PrPsc}$. Normally $\alpha$-syn assumes an $\alpha$-helical conformation, but in particular pathological conditions, the protein can change its conformation to a $\beta$-sheet-rich structure that is prone to aggregate, forming toxic species (oligomers, fibrils and ribbons) (Baba et al., 1998) (Fig. 1A). These aggregated forms of $\alpha$-syn are the main component of LBs in PD brains (Lippa et al., 1998). In 2008, two reports showed that PD patients had developed $\alpha$-syn-positive LBs in grafted fetal mesencephalic dopaminergic neurons that were transplanted in the striatum, as an attempted therapeutic intervention (Kordower et al., 2008; Li et al., 2008), showing that in humans, aggregated $\alpha$-syn can propagate to healthy cells, supporting the hypothesis that PD is a prion-like disease.

Many in vitro studies have shown how to purify $\alpha$-syn seeds that can be used to build up amyloid-like fibrils similar to those in LBs (Conway et al., 2001, 1998; Uversky, 2007). Using these $\alpha$-syn seeds, it has been 
confirmed in vitro and in vivo, that misfolded $\alpha$-syn can propagate following the prion-like paradigm (Fig. 1B). Indeed, it was shown that exogenously assembled $\alpha$-syn fibrils were able to recruit and convert their soluble counterparts into elongating fibrils when internalized by different cell types, both in culture and injected in the brain of living animals (Luk et al., 2012a, 2009; Volpicelli-Daley et al., 2011). Moreover, it was demonstrated that a very small amount of preformed fibrils is sufficient to start the conversion process of native $\alpha$-syn proteins, suggesting that template recruitment is probably a self-perpetuating action (Luk et al., 2009; Volpicelli-Daley et al., 2011). Thus, misfolded $\alpha$-syn could spread from affected to unaffected regions of the brain, leading to neurodegeneration and progression of PD pathology.

The prion-like spreading of $\alpha$-syn is consistent with the Braak's staging of PD. According to this study, PD progression can be categorized in six different stages and every stage is associated with a particular neurological structure positive for LBs (Braak et al., 2003). The type and severity of the symptoms are correlated with the advance from one stage to another (Braak et al., 2003). PD progression could occur by the spreading of $\alpha$-syn aggregates in the brain through two possible routes: (1) from the olfactory bulb with anterograde progression into the temporal lobe; or (2) from the gastric epithelial, via the vagal nerve to the basal midbrain and forebrain until reaching the cerebral cortex (Braak et al., 2006). The second hypothesis is supported by the finding of $\alpha$-syn aggregates in intestinal tissues of PD patients, particularly in neurons of the enteric system (Gelpi et al., 2014; Ruffmann et al., 2018). Moreover, local injections of $\alpha$-syn into the vagal nerve - a direct physical connection between gut neurons and the central nervous system (CNS) - of rats, can induce PD-like pathology in the CNS (Holmqvist et al., 2014; Ulusoy et al., 2013). These and other recent reports support the hypothesis that $\alpha$-syn aggregates can be transferred from gut to brain.

Recently, new studies have focused on one aspect of prion like behavior in synucleinopathies: The presence of different strains of the aggregated protein (Bousset et al., 2013; Peelaerts et al., 2015). Indeed, in prion disease, a variety of strains that are believed to be the consequence of different conformations of $\operatorname{PrP} \mathrm{P}^{\mathrm{sc}}$ exist (Bruce, 1993). Moreover, prion strains show different cell tropism with consequently different physiopathological patterns (Bruce, 1993). Similarly, it was suggested that native unfolded monomeric $\alpha$ syn can be folded into different intermediate molecules (Uversky, 2003; Pieri et al., 2016). All these folding 
intermediates exhibit specific amino acid stretches that define specific intermolecular interactions (Brundin and Melki, 2017). Longitudinal and lateral interactions can occur between molecules that exhibit the same conformation, thus leading to the establishment of a thermodynamically stable assembly (Brundin and Melki, 2017). The intermolecular interactions within different assemblies might define the origin of the different strains (Brundin and Melki, 2017). Until now, two strains of $\alpha$-syn have been identified: fibrils and ribbons (Bousset et al., 2013). These strains have different structures and different seeding and propagation abilities (Bousset et al., 2013). In fact, it was demonstrated that $\alpha$-syn fibrils and ribbons faithfully propagate their intrinsic structure, but show different membrane binding properties and different penetration propensities that could explain the differences in their toxicity (Bousset et al., 2013). As of yet, there is no evidence that the different $\alpha$-syn strains really exist in the human brain; but their existence could explain why $\alpha$-syn aggregates in the different synucleinopathies exhibit different pathogenic effects (Halliday et al., 2011; McCann et al., 2014). However, further molecular and cell biological studies are necessary to probe this hypothesis and to understand the pathological diversity seen in the different $\alpha$-synrelated diseases.

\section{Spreading properties of different $\alpha$-syn aggregated forms}

Monomeric $\alpha$-syn is soluble, and upon oligomerization the protein remains soluble (Wang et al., 2016). In a misfolded conformation, when the fibrillization process is started, $\alpha$-syn becomes insoluble and assumes self-aggregate properties (Wang et al., 2016). Plenty of evidence supports the hypothesis that PD pathogenesis is due to a process of $\alpha$-syn oligomerization and fibrillary growth (Osterberg et al., 2015; Pieri et al., 2012; Taschenberger et al., 2012; Tsigelny et al., 2008). However, it is still unknown which specific molecular mechanism influences native $\alpha$-syn to change its conformation and properties, producing aggregated forms. Understanding the structure of $\alpha$-syn species could give information about their toxicity and could help in the development of PD treatments. 
During aging, the levels of soluble $\alpha$-syn protein in human substantia nigra (SN) increase (Li et al., 2004). In neurons, the expression of $\alpha$-syn is regulated by post-translational protein stabilization, a mechanism that seems to be crucial for different neurodegenerative diseases (Li et al., 2004). The increase in the levels and the stability of $\alpha$-syn can synergistically produce an accumulation of oxidatively modified $\alpha$-syn by promoting the aggregation of the protein, thus increasing the risk to trigger PD pathogenesis (Li et al., 2004). Moreover, with age, $\alpha$-syn also changes its interneuronal localization (Chu and Kordower, 2007). In fact, in young individuals, the protein is mainly located in the synaptic terminals while its levels in the soma are low. Instead, in older individuals, $\alpha$-syn becomes more concentrate in the cell body of the neurons (Chu and Kordower, 2007). This aging-related $\alpha$-syn accumulation in the soma could be considered as a marker of a pre-LB state in neurons (Collier et al., 2017).

Distinct spreading properties and toxic behaviors have been described for the different $\alpha$-syn species. Recently, an in vivo experiment showed that injections of different $\alpha$-syn assemblies (oligomers, ribbons and fibrils) into rat SN have different effects on synaptic transmission, after acute exposure (Peelaerts et al., 2015). Peelaerts et al. found that $\alpha$-syn fibrils are more toxic than the oligomers and ribbons, causing more severe synaptic impairments and motor deficits (Peelaerts et al., 2015). The authors also found that $\alpha$-syn oligomers spread more efficiently than ribbons and fibrils, but only ribbons and fibrils are able to induce LB-like pathology in dopaminergic neurons, four months after injection (Peelaerts et al., 2015). These findings indicate that distinct $\alpha$-syn assemblies have different spreading capacities, display different seeding propensities, and induce different pathological phenotypes in vivo. Indeed, it was found that monomeric and oligomeric $\alpha$-syn, but not the fibrillary form, are rapidly transferred after injection into the olfactory bulb (OB) of wild type (WT) mice, to directly connected brain regions (Rey et al., 2013). The fact that oligomeric forms of $\alpha$-syn propagate throughout the brain more quickly than the higher aggregated forms suggests that they could use different mechanisms of spreading. As mentioned above, different mechanisms seem to be involved in $\alpha$-syn cell-to-cell transfer, and different $\alpha$-syn species could have a preferential way of spreading. 
In the future, it will be important to understand the exact contribution of each $\alpha$-syn species to the prionlike spreading of PD pathology by knowing their transfer and seeding properties, as well as their toxic effects on recipient cells. All these still missing data could help to develop efficient clinical treatments for PD.

\section{In vivo evidences for the spreading and seeding capabilities of $\alpha$-syn}

The hypothesis of the prion-like spreading of $\alpha$-syn described above is supported by an increasing amount of in vivo data. Since the reports of Kordower et al. and Li et al. in 2008, showing that LB pathology can propagate from the brain of PD patients to embryonic grafted neurons transplanted years before (Kordower et al., 2008; Li et al., 2008), numerous publications have demonstrated that pathogenic $\alpha$-syn can spread from disease cells to the healthy ones, in a prion-like fashion (Brundin and Melki, 2017). The properties of $\alpha$-syn aggregates, such as the ability to transfer from cell-to-cell and to induce newly formed aggregates on recipient cells, have also been described in animal models (Angot et al., 2012; Bernis et al., 2015; Desplats et al., 2009; Hansen et al., 2011; Krammer et al., 2009; Luk et al., 2012a; Masuda-Suzukake et al., 2013; Mougenot et al., 2012). Table 1 shows several experimental approaches that have been used to study the prion-like behavior of $\alpha$-syn aggregates in vivo.

\subsection{Transfer of $\alpha$-syn from host brain to engrafted cells}

Using a transgenic mouse model of PD, the propagation of $\alpha$-syn from disease neurons to engrafted tissue has been shown (Desplats et al., 2009). In detail, mouse cortical neuronal stem cells were transplanted into the hippocampus of transgenic mice expressing human $\alpha$-syn (Desplats et al., 2009). One month after transplantation, $15 \%$ of the engrafted cells were positive for human $\alpha-$ syn, and the number of grafted cells containing inclusion bodies increased with time (Desplats et al., 2009). Other studies using engrafted tissue have also shown direct host-to-graft transmission of $\alpha$-syn in vivo. By transplanting mouse dopaminergic 
neurons into the striatum of mice overexpressing human $\alpha$-syn under the control of the mouse $\alpha$-syn promoter, the transfer of $\alpha$-syn between host and grafted neurons was demonstrated 6 months after transplantation (Hansen et al., 2011). Additionally, transfer of $\alpha$-syn from host-to-graft has also been reported in rats (Angot et al., 2012; Kordower et al., 2011). Fetal rat ventral mesencephalon was engrafted into the dopamine-depleted striatum of rats. One month after the transplants, the animals received an intrastriatal injection of an adeno-associated virus (AAV) vector expressing human- $\alpha$-syn, rostral to the grafts and no direct infection of the grafts was ensured (Kordower et al., 2011). By detecting human $\alpha$-syn immunoreactivity, the propagation of $\alpha$-syn was found in $5.7 \%$ of the engrafted rat dopaminergic neurons, 5 weeks after the AAV injection (Kordower et al., 2011). Another study showed the transfer of $\alpha$-syn from rat host brains overexpressing human $\alpha$-syn to grafted dopaminergic neurons (Angot et al., 2012). In this case, an interaction between the human $\alpha$-syn and rat $\alpha$-syn within the grafted neurons was also demonstrated, suggesting a seeding activity of the transferred $\alpha$-syn on the endogenous $\alpha$-syn.

These findings are in accordance with the observations done in the brains of PD patients transplanted with embryonic neurons and developed LB-like pathology in the engrafted tissue (Kordower et al., 2008; Li et al., 2008), which call into question the cell-based therapies as useful treatment for PD.

\subsection{Spreading of $\alpha$-syn following intracerebral administration}

Several studies have reported that intracerebral injections of preformed $\alpha$-syn aggregates induce LB-like inclusion formation, leading to synaptic impairments and neuronal death (Abdelmotilib et al., 2017; Luk et al., 2012b; Volpicelli-Daley et al., 2011). Notably, $\alpha$-syn positive inclusions in the brain of injected animals can be found in regions that are far from the injection site, which suggest the spreading of the $\alpha$-syn pathology from cell-to-cell (Luk et al., 2012b). Indeed, intracerebral injection of aggregated $\alpha$-syn into WT mice or transgenic mice overexpressing either human WT $\alpha$-syn or human $\alpha$-syn with the familial A53T mutation, can cause the spreading of $\alpha$-syn pathology in the CNS of injected mice (Luk et al., 2012a; Mougenot et al., 2012; Sacino et al., 2014a). The intrastriatal administration of preformed $\alpha$-syn fibrils in 
WT mice led to the propagation of pathological $\alpha$-syn in anatomically interconnected brain areas (Luk et al., 2012a). In a recent study, it was shown that the spreading of $\alpha$-syn fibrils and its pathology can be significantly reduced by deletion of the lymphocyte-activation gene 3 (LAG3), a transmembrane protein that selectively binds $\alpha$-syn fibrils (Mao et al., 2016). In fact, LAG3-deficient mice injected with preformed $\alpha$ syn fibrils in the dorsal striatum exhibited $50 \%$ fewer $\alpha$-syn positive inclusions in neurons of SNpc, compared to $\alpha$-syn-injected WT mice (Mao et al., 2016). These findings suggest that LAG3 is important for the spreading of the $\alpha$-syn-induced pathology and the development of PD-related motor impairments.

One of the first brain areas where $\alpha$-syn positive inclusions are formed in PD patients is the $O B$ and the anterior olfactory nucleus (Braak et al., 2003). Almost $90 \%$ of PD patients develop smell impairments, and the smell loss starts years before the appearance of motor symptoms (Doty, 2012). Several in vivo studies have shown that $\alpha$-syn pathology can spread from the OB to other brain areas. Mason et al. demonstrated that three months after the injection of $\alpha$-syn fibrils into the $\mathrm{OB}$ of non-transgenic mice, $\alpha$-syn positive inclusions were found deep into the temporary lobe (in the piriform and entorhinal cortices, amygdala and the hippocampus) (Mason et al., 2016). In addition, it was shown that $\alpha$-syn fibrils injected into the OB of WT mice can induce the transformation of endogenous $\alpha$-syn into pathological aggregates, which propagate transneuronally to distant brain regions over a period of one year (Rey et al., 2016). However, two years post-injection, no additional brain regions exhibited $\alpha$-syn deposits, suggesting that the transfer of $\alpha$-syn pathology can be affected by early $\alpha$-syn-induced neuron loss, which compromises the neural circuitry involved in its spreading, or by proteolytic mechanisms in resilient neurons of WT mice which facilitate $\alpha$-syn degradation (Rey et al., 2018). On the other hand, no $\alpha$-syn-positive inclusions were detected in mouse brains 21 months post-intranasal administration of preformed $\alpha$-syn fibrils, suggesting that aggregates of $\alpha$-syn protein cannot pass through the nasal mucosa (Masuda-Suzukake et al., 2013). Inoculation of preformed $\alpha$-syn fibrils into different brain regions (OB, SNpc, striatum, entorhinal cortex and hippocampus) of rats, mice, and monkeys, have demonstrated that $\alpha$-syn pathology can spread in vivo from several areas to other regions in the CNS (Abdelmotilib et al., 2017; Luk et al., 2012a; Masuda-Suzukake et al., 2014; Paumier et al., 2015; Rey et al., 2013; Sacino et al., 2014a; Shimozawa et al., 2017). However, 
different laboratories have reported contradictory data regarding the spreading patterns and seeding capacities of injected $\alpha$-syn fibrils. In some studies, WT animals develop $\alpha$-syn positive inclusions after injection of $\alpha$-syn fibrils, whereas, in other studies, $\alpha$-syn-transgenic animals, but not WT animals, exhibit $\alpha$ syn pathology post-injection of the fibrils. These differences could be due to several reasons. For instance: a) the preparation of $\alpha$-syn fibrils; b) the genotype and age of experimental animals; c) the injection site; d) the concentration of $\alpha$-syn fibrils; e) the volume of injected material and speed of injection, and f) time post-injection when the analyses were made. Another source of controversy is the ability of $\alpha$-syn seeds of human origin to induce the formation of $\alpha$-syn positive inclusions in mice. While, some studies have shown that both human and mouse recombinant $\alpha$-syn fibrils are able to efficiently induce $\alpha$-syn pathology in injected mice, other authors have reported the existence of a cross-seeding species barrier for human and mouse $\alpha$-syn. Molecular compatibility between the exogenous $\alpha$-syn fibrils and the endogenous protein has been proposed as a key determinant of its seeding activity (Luk et al., 2016). In addition, most of the studies reviewed here have shown that the spreading of $\alpha$-syn pathology principally occurs along anatomically interconnected brain regions (Luk et al., 2012a; Recasens et al., 2014; Rey et al., 2013). Conversely, Sorrentino et al., demonstrated that the spreading of $\alpha$-syn pathology in $\alpha$-syn-transgenic and nontransgenic mice after intrastriatal injection of $\alpha$-syn fibrils takes place in a sparse manner, which does not necessarily follow neuroanatomic connectivity (Sorrentino et al., 2017). This data suggests that other mechanisms besides trans-synaptic spreading, could be involved in the transmission of $\alpha$-syn aggregates throughout the brain. In the next section, we will review possible cellular mechanisms that might underlie the cell-to-cell propagation of $\alpha$-syn.

\subsection{Spreading of $\alpha$-syn following inoculation of brain homogenates derived from PD patients}

The spreading of $\alpha$-syn pathology in vivo has also been demonstrated by intracerebral inoculation of samples derived from PD patients, in mice and monkeys. Recasens et al. isolated $\alpha$-syn-containing extracts from the SN of PD patients, and injected them into the SN of mice (Recasens et al., 2014). These extracts 
induced inclusion formation and nigrostriatal degeneration in WT, but not $\alpha$-syn-deficient mice, indicating that endogenous $\alpha$-syn expression is required for spreading of the pathology (Recasens et al., 2014). In fact, the injection of $\alpha$-syn-containing extracts in WT mice increased the conversion of soluble endogenous $\alpha$-syn into aggregated forms, while inducing the formation of $\alpha$-syn-positive inclusions within nigral neurons and anatomically interconnected regions, both anterogradely and retrogradely (Recasens et al., 2014). Moreover, injection of $\alpha$-syn-containing extracts in the striatum of macaque monkeys induced a marked loss of dopaminergic neurons in the SNpc and a widespread distribution of $\alpha$-syn pathology (Recasens et al., 2014). Furthermore, intrastriatal injection of brain extracts from patients with other synucleinopathies, such as multiple system atrophy (MSA) and probable incidental LB disease (iLBD), confirmed prion-like propagation of $\alpha$-syn in the brain of transgenic mice expressing human WT $\alpha$-syn (Bernis et al., 2015). Similarly, the injection of brain homogenates from patients with Dementia with LB (DLB) triggered $\alpha$-syn pathology in WT mice (Masuda-Suzukake et al., 2013). While DLB homogenates did not induce a glial response or neuronal loss (Masuda-Suzukake et al., 2013), another study has shown that mice injected with MSA-derived brain homogenates exhibit prominent astrocytic and microglial activation and develop progressive signs of neurologic dysfunction (Watts et al., 2013). These differences support the hypothesis that different $\alpha$-syn strains might exist in each disease (PD, MSA, iLBD and DLB), which could explain why the $\alpha$-syn coming from each synucleinopathy sample has different pathological properties. However, more studies are required to corroborate this hypothesis and to determine the physicochemical and biological differences among them.

\subsection{Transfer of $\alpha$-syn from the periphery to the CNS}

Notably, transfer of $\alpha$-syn throughout the CNS after peripheral administration has also been reported. Interneuronal transfer of $\alpha$-syn in vivo was shown by injecting AAV-human- $\alpha$-syn vector into the rat vagus nerve (Ulusoy et al., 2013). After vagal AAV injections, exogenous $\alpha$-syn was transferred to the medulla oblongata, and then, it propagated in a caudo-rostral way to the pons, midbrain and forebrain (Ulusoy et 
al., 2013). Interestingly, $\alpha$-syn transfer occurs more efficiently in healthy neurons than in neurodegenerating ones (Ulusoy et al., 2015). This suggests that $\alpha$-syn transfer does not occur through a passive release from damaged or dead neurons, but via an active mechanism. Peelaerts et al. demonstrated that $\alpha$-syn strains (fibrils and ribbons) are able to cross the blood-brain barrier and distribute along different brain regions when they are repeatedly injected in rat tail vein (Peelaerts et al., 2015). It was also shown that $\alpha$-syn-rich extracellular vesicles derived from erythrocytes, can cross the blood-brain barrier via adsorptive-mediated transcytosis (Matsumoto et al., 2017). These extracellular vesicles co-localize with microglia, and can cause microglial inflammatory responses in the brain (Matsumoto et al., 2017) (Fig. 2A). Moreover, intramuscular injection of $\alpha$-syn fibrils in $\alpha$-syn-transgenic mice induced a rapid, widespread distribution of $\alpha$-syn inclusion pathology in the CNS, accompanied by astrogliosis, microgliosis, and motor impairments (Sacino et al., 2014b). Interestingly, according to Braak's hypothesis of PD stages, the LB pathology starts in the myenteric and submucosal neurons of the enteric nervous system, and from there spreads to the CNS (Braak et al., 2003). A recent study showed that microbiota from PD patients induces motor disturbances in $\alpha$-syn-overexpressing mice, but not in WT mice (Sampson et al., 2016). Another study showed that rats and non-human primates that received enteric injections of either preformed $\alpha$-syn fibrils, or AAV-human-A53T- $\alpha$-syn, developed gastrointestinal dysfunction, while the spreading of $\alpha$-syn pathology from the periphery to the CNS and its subsequent propagation occurred in a very inefficient way (Manfredsson et al., 2018). Dysregulation of the brain-gut-microbiota axis might be associated with the pathogenesis of PD. Indeed, gastrointestinal disturbances frequently precede motor symptoms in PD, supporting the hypothesis that the pathology spreads from the gut to the brain (Mulak and Bonaz, 2015). Overgrowth of intestinal bacterial may induce systemic inflammation that activates enteric neurons and enteric glial cells, and might contribute to the initiation of $\alpha$-syn misfolding and aggregation (Mulak and Bonaz, 2015). Further work is needed to understand the brain-gut-microbiota axis interactions in PD pathology and to identify peripheral biomarkers within the enteric nervous system that allow earlier diagnosis of the disease. Novel therapeutic approaches aimed to enhance the intestinal epithelial barrier integrity in PD patients might have an impact in PD progression. 


\section{In vitro models as tools for the study of $\alpha$-syn spreading mechanisms}

The seeding capacities of $\alpha$-syn aggregates, and the subsequent propagation of the pathological forms from one cell to the other, have also been evaluated using in vitro models. Although less physiological compared to the in vivo studies, these models have allowed further investigation of the mechanisms of intercellular transfer and seeding properties of $\alpha$-syn aggregates. In table 2 we sum up in vitro studies correlating different $\alpha$-syn species with different mechanisms of spreading.

The involvement of different cell types in the intercellular transmission of $\alpha$-syn aggregates has been evaluated by using homotypic and heterotypic co-culture models, where different cell types were assayed as donor (cells containing $\alpha$-syn aggregates) or acceptor (naive recipient cells). Thus, the transfer of $\alpha$-syn has been reported to take place from neuron-to-neuron (Abounit et al., 2016; Freundt et al., 2012), astrocyte-to-astrocyte (Loria et al., 2017; Rostami et al., 2017), neuron-to-astrocyte (Lee et al., 2010; Loria et al., 2017) and neuron-to-oligodendrocyte (Reyes et al., 2014).

To unravel the mechanism(s) underlying the intercellular propagation of $\alpha$-syn aggregates it is necessary to turn to in vitro models. Here we present a comprehensive, up-to-date summary of relevant in vitro studies that have assessed possible mechanisms of $\alpha$-syn transfer (Fig. 2).

\subsection{Different ways of $\alpha$-syn secretion}

$\alpha$-Syn has been identified in different biofluids, including human CSF, serum/plasma, red blood cells and saliva (Devic et al., 2011; El-Agnaf et al., 2006, 2003; Mollenhauer et al., 2008; Wang et al., 2015). These findings support the hypothesis that $\alpha$-syn can be secreted to the extracellular space, though it is still not clear how this process takes place. Many studies have demonstrated the existence of different secretory pathways for each $\alpha$-syn species. Lee et al. reported that, while $\alpha$-syn is predominantly localized in the cytosol, a portion of the cellular $\alpha$-syn is located in the lumen of vesicles and secreted from neuronal cells 
via non-classical endoplasmic reticulum/Golgi-independent exocytosis (Lee et al., 2005) (Fig. 2B). Moreover, $\alpha$-syn localized in vesicles is more prone to the aggregation than the cytoplasmic $\alpha$-syn, and aggregated forms are released from the cells (Lee et al., 2005). It was demonstrated in neuroblastoma cells and primary neurons that stress-conditions increase the translocation of $\alpha$-syn into vesicles, thus causing its subsequent release to the extracellular space (Jang et al., 2010). Furthermore, the misfolded conformation of the protein could be critical for vesicle translocation and secretion (Jang et al., 2010). Only a small fraction of $\alpha$-syn was detected in extracellular vesicles (Fig. 2B), but it is known that the increase of cytoplasmic protein levels may contribute to an increased release of the protein (Jang et al., 2010). In fact, a recent study using neurons derived from induced pluripotent stem cells, and expressing triplication of the SNCA gene, demonstrated high levels of $\alpha$-syn secretion, and that neighboring neurons are able to take it up from the medium (Reyes et al., 2015).

Different studies have also demonstrated that monomeric, oligomeric and fibrillary $\alpha$-syn can be released in association with exosomes (Fig. 2B). These structures are small vesicles, generated from the fusion of multivesicular bodies (MVBs) with the plasma membrane, and released into the extracellular medium (Colombo et al., 2014). Exosomes are secreted from various cell types, including neurons and astrocytes, and therefore it has been proposed that they could have a regulatory function at the synapses and at the intercellular exchange of membrane proteins (Fauré et al., 2006). Oligomeric and monomeric $\alpha$-syn species, both free and within exosomes, are detected in the conditioned medium of neuroblastoma cells expressing $\alpha$-syn following a calcium-dependent mechanism (Emmanouilidou et al., 2010). These findings suggest that $\alpha$-syn secretion is an active and regulated mechanism that can occur via exosomes. Moreover, the release of $\alpha$-syn within exosomes increases under lysosomal dysfunction, with a subsequent increment of $\alpha$-syn transfer (Alvarez-Erviti et al., 2011). It was found that $\alpha$-syn oligomers within exosomes enter more easily into neighboring cells as compared to free $\alpha$-syn oligomers, which contributes to increased toxic effect (Danzer et al., 2012). Of interest, exosomes containing pathogenic species of $\alpha$-syn are found in CSF of PD patients and are able to induce the oligomerization of soluble $\alpha$-syn in recipient cells, which suggests that 
exosomes could act as mean for spreading of the pathology (Stuendl et al., 2016). However, whether exosomes containing $\alpha$-syn fibrils are up taken by neighbor cell has yet to be demonstrated.

Interestingly, with age the number of exosomes and their content seem to vary (Mitsuhashi et al., 2013). For example, findings from in vitro models suggest that senescent cells release more proinflammatory cytokines-containing exosomes than younger cells (Mitsuhashi et al., 2013). This phenomenon could induce cellular stress and produce a state prone to an increased protein degradation. However, more studies are needed to specifically address how different aging factors could modulate the various mechanisms of $\alpha$-syn secretion, accelerating PD onset.

In dopaminergic neuron-like cells, monomeric and high molecular weight species of $\alpha$-syn can be secreted by exophagy, an autophagic secretory mechanism (Fig. 2B). It was found that tubulin polymerizationpromoting protein (TPPP/p25 $\alpha$ ) increases $\alpha$-syn aggregation and inhibits autophagosomal-lysosome fusion promoting this unconventional way of secretion (Ejlerskov et al., 2013). This suggests that $\alpha$-syn can also be secreted via exosome-independent mechanisms, such as exophagy, and that factors that alter autophagyrelated processes can also influence $\alpha$-syn release from the cells.

Together, all these studies provide robust evidence that $\alpha$-syn can be secreted into the extracellular space; however, the exact mechanism of release remains obscure. More studies are necessary to identify the factors that determine whether $\alpha$-syn aggregates are secreted via exosomes, or by an exosomeindependent pathway.

\subsection{The uptake of $\alpha$-syn}

Uptake of pathologic $\alpha$-syn contributes to the seeding of endogenous protein aggregation, and to the cellto-cell spreading of the pathology (Brahic et al., 2016). Following secretion, $\alpha$-syn can be taken up by surrounding cells. How released $\alpha$-syn (of all $\alpha$-syn species) can be internalized by different cell types is still a matter of study. 
$\alpha$-Syn uptake can occur in a passive way (by diffusion), or in an active way (by endocytosis). Different mechanisms are known to mediate the internalization of different $\alpha$-syn species (Fig. 2C). $\alpha$-Syn is known to directly interact with lipids or proteins at the plasma membrane, which could facilitate its entering in a nonspecific way (Auluck et al., 2010). Several studies have shown that $\alpha$-syn associates to lipid rafts, and more specifically to the glycolipid, ganglioside GM1, which is abundantly expressed in the brain (Fortin et al., 2004; Olive et al., 1995). Whether and how this interaction could lead to $\alpha$-syn internalization is not clear yet.

On the other hand, the internalization of different forms of $\alpha$-syn has been largely studied in neuronal cells. Fibrils and oligomeric $\alpha$-syn species can be internalized by endocytosis, and this process can be inhibited by low temperature exposure (Lee et al., 2008). Conversely, monomeric forms are unaffected by low temperature, and can be internalized quickly by diffusion (Lee et al., 2008). Various type of endocytosis can mediate $\alpha$-syn internalization: caveolin or clathrin-dependent pinocytosis, actin-dependent macropinocytosis and actin-dependent phagocytosis (Hansen et al., 2011; Lee et al., 2005, 2008). In vivo, it was also observed that exogenous $\alpha$-syn can be internalized by a dynamin-dependent process (Hansen et al., 2011). The inhibition of dynamin contributes to block the entering of endocytic vesicles with a concomitant accumulation of $\alpha$-syn oligomers and fibrils on the cell membrane (Lee et al., 2008). Many studies have attempted to identify the receptor(s) involved in $\alpha$-syn endocytosis. It was found that the $\alpha 3-$ subunit of $\mathrm{Na}^{+} / \mathrm{K}^{+}$-ATPase is able to bind exogenous $\alpha$-syn, facilitating its uptake by neurons (Shrivastava et al., 2015). This interaction depends on the structure of the protein: fibrils show a stronger affinity compared to oligomers, and no affinity was observed in monomers (Shrivastava et al., 2015). $\alpha$-Syn fibrils are also able to bind heparan sulfate proteoglycans (HSPGs) on the surface of the cells, and the internalization of the fibrils can be blocked by compounds that inhibit this binding (Holmes et al., 2013) (Fig. 2C). Recently, screening studies have identified transmembrane proteins that can bind to $\alpha$-syn: neurexin1 $\beta$, amyloid- $\beta$ precursor-like protein-1 and LAG3 (Mao et al., 2016; Shrivastava et al., 2015). Only LAG3 shows a selective binding for $\alpha$-syn fibrils but not for monomers (Fig. 2C). Moreover, this binding is specific for $\alpha$-syn fibrils, since tau fibrils, amyloid- $\beta$ oligomers and amyloid- $\beta$ fibrils do not bind to LAG3 (Mao et al., 
2016). LAG3 is a member of the immunoglobulin superfamily of receptors identified on different immune cells: activated human natural killer cells, T cells, B cells and dendritic cells (Andrews et al., 2017; Kisielow et al., 2005; Triebel et al., 1990; Workman et al., 2009). It is also expressed in the brain, in a restricted population of sparse cells in the cortex (Workman et al., 2002). However, the physiological role of LAG3 in the brain is still elusive. Also, it is unknown whether LAG3 expression in the brain follows a pattern consistent with those areas more vulnerable to $\alpha$-syn pathology. In primary neurons, depletion of LAG3 or a LAG3-antibody, reduces the uptake of $\alpha$-syn fibrils by endocytosis, thus preventing their spreading from cell-to-cell and the propagation of PD pathology (Mao et al., 2016). Moreover, another study has found that LAG3 is not only expressed in neurons, but also in microglia, creating great interest for future therapeutic approaches (Zhang et al., 2014). In fact, considering its regulatory role in the activation of peripheral immune cells, LAG3 may also contribute to the microglial reaction in neurodegenerative diseases. A very recent study has demonstrated that the expression levels of LAG3 are rather low in adult mouse brains, but its expression increases after prion infection (Liu et al., 2018). However, loss of LAG3 does not affect prion disease pathogenesis (Liu et al., 2018). Whether and how LAG3 may contribute to the pathogenesis of different prion diseases, is still unclear. The finding that LAG3 exclusively interacts with $\alpha$-syn fibrils supports the hypothesis that each $\alpha$-syn specie has a specific receptor involved in the uptake process. Other membrane proteins, besides HSPGs and LAG3, might have affinity for different $\alpha$-syn assemblies and affect their internalization. In addition, different $\alpha$-syn-receptors might mediate the uptake of $\alpha$-syn in different cell types. Further studies are needed to identify all $\alpha$-syn-receptors and other $\alpha$-syn-binding proteins that regulate its internalization, and to further define the molecular mechanisms that take place in this process.

Additionally, in vitro evidence demonstrates that $\alpha$-syn fibrils can be internalized by endocytosis (Desplats et al., 2009; Lee et al., 2005, 2008). After internalization, $\alpha$-syn fibrils co-localize with early endosomal (EEA1 and Rab5) and late endosomal/lysosomal (Rab7 and Lamp1) markers, suggesting that internalized $\alpha$ syn follows the endocytic pathway (Desplats et al., 2009; Lee et al., 2008). Once inside the lysosomes, the majority of $\alpha$-syn fibrils are degraded (Lee et al., 2008). Interestingly, astrocytes are also able to take up $\alpha$ - 
syn fibrils from the medium, and to degrade them with high efficiency in comparison to neurons (Loria et al., 2017). This suggests that astrocytes could play an important neuroprotective role by degrading pathologic $\alpha$-syn (Loria et al., 2017). Also, aggregates of $\alpha$-syn induce microglia activation after internalization through a clathrin-dependent process (Liu et al., 2007). Furthermore, a recent study has focused on the endocytic pathway followed by exosome-associated $\alpha$-syn (Delenclos et al., 2017). It is known that exosome-associated oligomeric $\alpha$-syn is more prone to be internalized by both neurons and microglia than free oligomeric $\alpha$-syn, (Bliederhaeuser et al., 2016; Danzer et al., 2012). Using different pharmacological inhibitors of caveolin-dependent and clathrin-dependent endocytosis pathways, and micropinocytosis inhibitors, it was discovered that none of these mechanisms are involved in the uptake of exosome-associated $\alpha$-syn (Delenclos et al., 2017). Also, it is not known whether HSPGs have a role in this process. To analyze the mechanism of internalization of exosome-associated $\alpha$-syn, it is necessary to consider that the way the exosomes are internalized can be different between the recipient cell and the cells that release them (Feng et al., 2010; Mulcahy et al., 2014).

Although a great amount of work has been done over the last decade, an understanding of the molecular and cellular mechanisms that regulate $\alpha$-syn secretion and uptake, and whether and how these contribute to the pathology transmission, is still lacking. Many important questions remain unanswered. For instance, it is still not known the exact mechanism of internalization of the different $\alpha$-syn assembly, or whether the different ways of internalization could lead to different subcellular localization and how this could affect the ability to seed the aggregation of the native $\alpha$-syn in the recipient cells. Further work is needed to better understand the cellular mechanism of exo/endocytosis of $\alpha$-syn and the molecular players involved in these processes. Whether these pathways constitute realistic therapeutic targets remains to be determined.

\section{3. $\underline{\alpha-S y n}$ spreading via tunneling nanotubes}


Tunneling nanotubes (TNTs) are transient tubular connections allowing direct communication between distant cells (Ariazi et al., 2017). TNTs are either open-ended, or connexin-positive gap junction-ended protrusions that transport several different cargoes inside (Abounit and Zurzolo, 2012; Gerdes et al., 2013). Many different cellular components such as organelles (including mitochondria and lysosomes), endocytic vesicles, proteins and calcium ions have been reported as common cargoes that are transferred between TNT-connected cells (Gerdes et al., 2013). Also, several pathogens are known to highjack TNTs to spread among connected cells (Ariazi et al., 2017). Particularly, misfolded proteins involved in various neurodegenerative diseases have been shown to be transferred through TNTs (Victoria and Zurzolo, 2017). The intercellular transfer of $\alpha$-syn fibrils via TNTs was first reported by Abounit et al. using a co-culture of neuron-like cells and primary neurons (Abounit et al., 2016). Following internalization, $\alpha$-syn fibrils were directed to the lysosomal compartment, both in neuron-like cells and in primary neurons (Abounit et al., 2016). Interestingly, fibrils are transferred from donor to acceptor cells occurs inside lysosomal vesicles, and principally in a cell-to-cell contact-dependent manner, via TNTs (Abounit et al., 2016) (Fig. 2D). After being transferred by TNTs, $\alpha$-syn fibrils can induce the aggregation of soluble endogenous $\alpha$-syn in acceptor cells (Abounit et al., 2016). This process suggests that somehow $\alpha$-syn fibrils can escape from the lysosome in which they were transferred, and seed the misfold conformation on the native $\alpha$-syn. In fact, it has been proposed that accumulation of $\alpha$-syn aggregates inside the lysosomes can cause dysfunction of this organelle by inducing membrane permeabilization, and loss of lysosomal integrity (Victoria and Zurzolo, 2017) (Fig. 2D). However, how $\alpha$-syn exits from lysosomes and how $\alpha$-syn-containing lysosomes move inside TNTs needs to be further explored. The idea that TNTs can be an efficient way for the propagation of the $\alpha$-syn pathology has been tested in different cell types, which are able to form functional TNTs and allow the transfer of different cellular components. Recently, Dieriks et al. confirmed $\alpha$-syn transfer through TNTs in SH-SY5Y cells, and in primary human brain pericytes derived from postmortem PD brains (Dieriks et al., 2017). In these cells, transfer via TNTs is not restricted to $\alpha$-syn, since TNT-mediated transfer of fluorescent membrane and control proteins was also observed (Dieriks et al., 2017). The exchange of membrane through TNTs could have a crucial role in the intercellular transport of $\alpha$-syn aggregates. 
Importantly, transfer through TNTs occur rapidly, but is dependent on the size of the transported cargo (Dieriks et al., 2017). In situ inspection of PD brains showed that some pericytes of the OB contain $\alpha$-syn positive inclusions similar to those found in neurons, and they can connect through TNT-like structures, suggesting that TNTs could actually be involved in the spreading of PD pathology throughout the brain (Dieriks et al., 2017). In addition, Rostami et al. showed that human astrocytes, derived from embryonic stem cells, can transfer $\alpha$-syn oligomers via direct cell-to-cell contact, or via TNTs (Rostami et al., 2017). $\alpha$ Syn-containing astrocytes form significantly more TNTs than healthy astrocytes, and the exposure to $\alpha$-syn oligomers induces an increase of TNT formation over time (Rostami et al., 2017). Moreover, $\alpha$-syn transfer from donor astrocytes to healthy acceptor astrocytes triggers the transport of mitochondria in return, indicating that, while TNTs could act as a mean for the spreading of $\alpha$-syn, they could also serve as a rescue mechanism. Using latrunculin-B as a pharmacological approach to inhibit TNT formation, the transfer of both $\alpha$-syn and mitochondria was reduced but not completely blocked, suggesting that other mechanisms beside TNTs could be involved in the transfer between astrocytes (Rostami et al., 2017). In fact, Loria et al. showed that, very inefficiently, astrocytes can secrete $\alpha$-syn fibrils into the medium, while most of the transfer occurs in a cell-to-cell contact dependent manner (Loria et al., 2017). Altogether these data strongly suggest that TNTs participate in the spreading of $\alpha$-syn aggregates, there are still several open questions that need to be addressed to fully understand the role of TNTs in the development of PD pathology: a) Are TNTs formed in neurons and astrocytes in vivo? b) Are TNTs increased in pathological conditions, allowing the transfer of aggregated $\alpha$-syn? c) Targeting TNT formation will decrease the spreading of $\alpha$-syn pathology? d) Are TNTs allowing the transfer of beneficial cargoes too? Therefore, targeting them could potentially cause adverse effects? More studies are required to properly answer these questions.

\subsection{Trans-synaptic propagation of $\alpha$-syn}


Increasing evidence coming from in vivo studies has shown that $\alpha$-syn aggregates preferentially spread along anatomically interconnected brain regions (Luk et al., 2012a; Mason et al., 2016; Masuda-Suzukake et al., 2013; Recasens et al., 2014; Rey et al., 2013), suggesting that $\alpha$-syn could possibly propagate via a transsynaptic mechanism (Fig. 2E).

A recent study showed that endogenous $\alpha$-syn can be released from neurons in vivo and in vitro, in response to neuronal activity (Yamada and Iwatsubo, 2018). Thus, increased neuronal activity triggered a rapid release of $\alpha$-syn, while its blockage decreased the levels of extracellular $\alpha$-syn (Yamada and Iwatsubo, 2018). Interestingly, selective modulation of glutamatergic neurotransmission changes the extracellular levels of $\alpha$-syn, suggesting that the excitatory neuronal network is involved in the activity-dependent release of $\alpha$-syn (Yamada and Iwatsubo, 2018). In fact, the expression of endogenous $\alpha$-syn at the synapsis is mostly accompanied by the expression of the excitatory presynaptic marker, vesicular glutamate transporter-1, indicating that $\alpha$-syn mainly localizes in glutamatergic terminals (Taguchi et al., 2016). Release of $\alpha$-syn is a calcium-regulated process that depends on the activation of sulfonylurea receptor 1sensitive ATP-regulated potassium channels, a receptor distributed throughout the cytoplasm of GABAergic neurons from where the ATP-dependent channel regulates GABA release (Emmanouilidou et al., 2016). Thus, targeting sulfonylurea receptors could be a possible way to alter the $\alpha$-syn secretory pathway. However, it is still not known whether aggregated $\alpha$-syn can also be released in response to neuronal activity, and whether its release is regulated by the same factors that control the release of native $\alpha$-syn.

Using primary neurons grown in microfluidic devices, which allow the separation of somatodendritic and axonal compartments in fluidically isolated chambers, the axonal transport of aggregated $\alpha$-syn has been studied. By using this approach, Freundt et al. demonstrated that $\alpha$-syn fibrils can be internalized by primary cortical neurons, transported inside axons in a fast and saltatory fashion, and subsequently transferred to second-order neurons following anterograde transport (Freundt et al., 2012). Axonal transport of $\alpha$-syn fibrils has been observed to take place in both anterograde and retrograde directions, with different efficiencies (Brahic et al., 2016). Quantification of $\alpha$-syn fibrils released after axonal transport revealed that retrograde transport is twice as efficient as anterograde transport (Brahic et al., 2016). 
Nevertheless, axon-to-soma transfer of $\alpha$-syn fibrils seems not to require synaptic contact, since transfer to still immature neurons was observed (Freundt et al., 2012). Similarly, neuron-to-neuron transfer of $\alpha$-syn fibrils occurred in a co-culture between mature and immature neurons (Abounit et al., 2016), suggesting that other mechanism(s) rather than trans-synaptic transfer could take place and allow the spreading of $\alpha$ syn aggregates, even in the absence of synaptic contacts. Moreover, in the absence of axonal degeneration, $\alpha$-syn fibrils can still be transferred after anterograde transport, indicating that $\alpha$-syn spreading occurs by an active mechanism, rather than simply by release into the medium from dead cells (Brahic et al., 2016). Despite the in vitro and in vivo evidence suggesting $\alpha$-syn trans-synaptic propagation, LB pathology does not strictly follow a pattern of spreading along interconnected brain regions, as would be expected if $\alpha$-syn aggregates were released from the presynaptic terminals and subsequently up taken by neighboring neurons (Surmeier et al., 2017).

Taken together, these data indicate that cell-to-cell propagation of $\alpha$-syn likely plays a role in the pathophysiology of PD, but this process occurs in a complex tissue architecture with multiple factors that regulate individual cell vulnerability, and which could influence $\alpha$-syn spreading. Further work is needed to identify the cellular mechanisms that lead $\alpha$-syn propagation and determine whether they may be leveraged for therapeutic strategies.

\section{Targeting the prion-like properties of $\alpha$-syn in PD: Therapeutic approaches and future perspectives}

Different approaches have been used to block the spreading and seeding of $\alpha$-syn. Recently, a de novodeveloped compound targeting $\alpha$-syn has been efficiently used to block the spreading of $\alpha$-syn pathology, in vitro and in vivo (Wrasidlo et al., 2016). This compound, called NPT100-18A, interacts with the Cterminus of $\alpha$-syn, reducing the oligomerization and its accumulation in neurons in vitro (Wrasidlo et al., 2016). In addition, in vivo administration of NPT100-18A overcomes motor deficits in $\alpha$-syn transgenic mice and reduces synaptic accumulation very rapidly (Wrasidlo et al., 2016). Another report suggests that mannitol could be also used as a treatment for PD. An in vitro assay shows that a low concentration of 
mannitol reduces $\alpha$-syn fibrils aggregation (Shaltiel-Karyo et al., 2013). In a Drosophila model of PD, mannitol also ameliorates behavioral deficiencies, and reduces the amount of $\alpha$-syn aggregates (ShaltielKaryo et al., 2013). Additionally, in an $\alpha$-syn transgenic mouse model, mannitol decreases $\alpha$-syn accumulation in the brain, suggesting a clearance effect (Shaltiel-Karyo et al., 2013).

Several immunotherapy approaches have been used to target $\alpha$-syn in animal models of PD. Bae et al. showed that antibodies against $\alpha$-syn induce extracellular $\alpha$-syn clearance by microglia, though not by astrocytes or neurons (Bae et al., 2012). Interestingly, intracerebral administration of anti- $\alpha$-syn antibodies block neuron-astroglia $\alpha$-syn transfer in $\alpha$-syn transgenic mice (Bae et al., 2012). Moreover, the intraperitoneal administration of a monoclonal antibody against $\alpha$-syn in non-transgenic mice intracerebrally injected with $\alpha$-syn fibrils reduced LB pathology, decreased dopaminergic neuron loss, and overcame motor deficits (Tran et al., 2014). Recently, passive immunization, using a new monoclonal antibody $1 \mathrm{H} 7$ against $\alpha$-syn, reduced accumulation of $\alpha$-syn in the axon (Spencer et al., 2017). Systemic administration of $1 \mathrm{H} 7$ antibody reduced transfer of $\alpha$-syn in the brain, ameliorating behavioral impairments in non-transgenic, $\alpha$-syn knock-out and $\alpha$-syn transgenic mice that received intracerebral injection of an $\alpha$ syn-carrying lentivirus (Spencer et al., 2017). In mouse models, both active and passive immunization strategies targeting $\alpha$-syn have helped to reduce spreading of $\alpha$-syn pathology, thus improving neurodegeneration and motor impairments in the animals (Mandler et al., 2014; Masliah et al., 2005). In humans, a small number of vaccine trials for $\alpha$-syn are being tested currently (Davis et al., 2018).

Another therapeutic approach targeted $\alpha$-syn by using micro-RNA to silence it. Although this strategy works in vitro, when the micro-RNA was co-administrated with $\alpha$-syn via an AAV vector, it caused inflammation and dopaminergic neuron loss, indicating that it uses is not suitable in vivo (Khodr et al., 2014).

Other therapeutic approaches have focused on increasing the clearance of $\alpha$-syn deposits in the brain. In PD patients, impaired autophagy, as well as a marked reduction in proteasomal activity, cause defects on protein degradation that accelerate $\alpha$-syn accumulation (Wong and Krainc, 2017). This condition can be exacerbated by aging, where autophagy is less efficient because the levels of autophagy-related proteins such as beclin 1, ATG5 and ATG7 are decreased (Wong and Holzbaur, 2015). These defects could contribute 
to increase $\alpha$-syn toxicity by inducing the accumulation of the protein. In fact, an increase in $\alpha$-syn levels with age have been observed in the human SN (Li et al., 2004). By inducing autophagy, some treatments have shown to remove $\alpha$-syn deposits (Rahman and Rhim, 2017). Treatments with clonidine, minoxidil and verapamil, showed removal of mutant A53T $\alpha$-syn in PC12 cells by increasing autophagy-inducing pathways (Williams et al., 2008). In addition, the autophagy enhancer, rapamycin has shown a neuroprotective effect by reducing $\alpha$-syn accumulation and $\alpha$-syn-induced neurodegeneration in $\alpha$-syn overexpressing mice (Crews et al., 2010). Recently, it was reported that the microRNA-7 accelerates the clearance of $\alpha$-syn aggregates in a differentiated human neural progenitor cell line, by promoting autophagy (Choi et al., 2018). Together these studies suggest that autophagy-enhancing approaches could be useful for PD treatment.

In addition, several groups have focused on different $\alpha$-syn-binding proteins as a therapeutic approach. In particular, the heat-shock protein 70 has been proposed as potential target for PD treatment, because it binds $\alpha$-syn in the extracellular space, reducing $\alpha$-syn oligomerization and $\alpha$-syn-induced toxicity (Danzer et al., 2011). A new finding revealed that LAG3 is a specific receptor for the endocytosis of $\alpha$-syn fibrils, providing a potential target for the development of PD treatments (Mao et al., 2016).

On the other hand, TNTs seem to be an important mechanism of communication between cells, and they could be used as a mean for the spreading of $\alpha$-syn aggregates (Abounit et al., 2016; Dieriks et al., 2017; Rostami et al., 2017; Victoria and Zurzolo, 2017). This suggests that TNTs are a new probable target for PD therapy. In fact, using a pharmacological approach to inhibit TNT formation, it was possible to reduce the transfer of $\alpha$-syn oligomers between cultured human astrocytes (Rostami et al., 2017). Moreover, TNTs could have a potential role facilitating the delivery of drugs among interconnected cells. Further work is needed to clarify whether TNTs play a role in vivo in the spreading of PD pathology, and whether they can be used as a therapeutic target to treat the disease.

Even though several therapeutic strategies have been assayed to target $\alpha$-syn aggregation and spreading, more studies are necessary to better characterize the mechanism(s) involved in the propagation of $\alpha$-syn aggregates (exo/endocytosis, exosomes, TNTs, trans-synapsis, adsorptive-mediated transcytosis, etc.). 
Identification of new potential targets is necessary for the development of more efficient PD therapies in the future.

\section{Conclusion}

Increasing evidence suggests that the propagation of $\alpha$-syn aggregates is coincident with the spreading of PD pathology throughout the brain. However, it is not yet well understood how aggregated $\alpha$-syn can transfer from cell-to-cell to induce synapto-toxicity and neurodegeneration. Although several in vivo models have been developed to study the prion-like properties of $\alpha$-syn aggregates, self-propagation of $\alpha$ syn seeds remains unproven. In addition, in vitro studies have shown that different mechanisms could be implicated in $\alpha$-syn cell-to-cell spreading, but whether these mechanisms take place in the brain of PD patients is still unknown. Taken together, in vitro and in vivo data strongly suggest that aggregated $\alpha$-syn can transfer through various cell types in the brain, inducing the aggregation of the endogenous protein. As of yet, more studies are necessary to go in depth into the aggregation process, and to understand the precise mechanism of $\alpha$-syn propagation in the brain. Moreover, it is not known whether the different familial PD-associated $\alpha$-syn mutations have different abilities to propagate throughout the brain, as they have different kinetics of aggregation and different physicochemical properties. Besides, it is unclear how defects of the cellular metabolism associated to aging (such as autophagy impairment, mitochondrial and proteasomal dysfunction) might contribute to $\alpha$-syn spreading and toxicity. A deeper understanding of the mechanisms driving $\alpha$-syn aggregation and intercellular propagation is important to understand PD pathogenesis, to identify new therapeutic targets and to develop therapeutic strategies to halt disease progression.

\section{Conflict of interest}

None of the authors have any conflicts of interest. 
Funding

This work was supported by the Agence Nationale de la Recherche [ANR-16-CE16-0019-01], Fondation pour la Recherche Médicale [FRM-2016-DEQ20160334896] and the grants from Vaincre Alzheimer and France Alzheimer foundations to $\mathrm{CZ}$.

\section{Acknowledgments}

The authors are thankful to Dr. Gonzalo Cordova and Maximiliana Bogan for the proofread of this manuscript.

\section{$\underline{\text { References }}$}

Abdelmotilib, H., Maltbie, T., Delic, V., Liu, Z., Hu, X., Fraser, K.B., Moehle, M.S., Stoyka, L., Anabtawi, N., Krendelchtchikova, V., Volpicelli-Daley, L.A., West, A., 2017. $\alpha$-Synuclein fibril-induced inclusion spread in rats and mice correlates with dopaminergic Neurodegeneration. Neurobiol. Dis. 105, 8498. https://doi.org/10.1016/j.nbd.2017.05.014

Abounit, S., Bousset, L., Loria, F., Zhu, S., de Chaumont, F., Pieri, L., Olivo-Marin, J.-C., Melki, R., Zurzolo, C., 2016. Tunneling nanotubes spread fibrillar $\alpha$-synuclein by intercellular trafficking of lysosomes. EMBO J. 35, 2120-2138. https://doi.org/10.15252/embj.201593411

Abounit, S., Zurzolo, C., 2012. Wiring through tunneling nanotubes--from electrical signals to organelle transfer. J. Cell Sci. 125, 1089-1098. https://doi.org/10.1242/jcs.083279

Alvarez-Erviti, L., Seow, Y., Schapira, A.H., Gardiner, C., Sargent, I.L., Wood, M.J.A., Cooper, J.M., 2011. Lysosomal dysfunction increases exosome-mediated alpha-synuclein release and transmission. Neurobiol. Dis. 42, 360-367. https://doi.org/10.1016/j.nbd.2011.01.029

Andrews, L.P., Marciscano, A.E., Drake, C.G., Vignali, D.A.A., 2017. LAG3 (CD223) as a cancer immunotherapy target. Immunol. Rev. 276, 80-96. https://doi.org/10.1111/imr.12519

Angot, E., Steiner, J.A., Lema Tomé, C.M., Ekström, P., Mattsson, B., Björklund, A., Brundin, P., 2012. Alphasynuclein cell-to-cell transfer and seeding in grafted dopaminergic neurons in vivo. PloS One 7 , e39465. https://doi.org/10.1371/journal.pone.0039465

Ariazi, J., Benowitz, A., De Biasi, V., Den Boer, M.L., Cherqui, S., Cui, H., Douillet, N., Eugenin, E.A., Favre, D., Goodman, S., Gousset, K., Hanein, D., Israel, D.I., Kimura, S., Kirkpatrick, R.B., Kuhn, N., Jeong, C., Lou, E., Mailliard, R., Maio, S., Okafo, G., Osswald, M., Pasquier, J., Polak, R., Pradel, G., de Rooij, B., Schaeffer, P., Skeberdis, V.A., Smith, I.F., Tanveer, A., Volkmann, N., Wu, Z., Zurzolo, C., 2017. Tunneling Nanotubes and Gap Junctions-Their Role in Long-Range Intercellular Communication during Development, Health, and Disease Conditions. Front. Mol. Neurosci. 10, 333.

https://doi.org/10.3389/fnmol.2017.00333 
Auluck, P.K., Caraveo, G., Lindquist, S., 2010. $\alpha$-Synuclein: membrane interactions and toxicity in Parkinson's disease. Annu. Rev. Cell Dev. Biol. 26, 211-233.

https://doi.org/10.1146/annurev.cellbio.042308.113313

Baba, M., Nakajo, S., Tu, P.H., Tomita, T., Nakaya, K., Lee, V.M., Trojanowski, J.Q., Iwatsubo, T., 1998. Aggregation of alpha-synuclein in Lewy bodies of sporadic Parkinson's disease and dementia with Lewy bodies. Am. J. Pathol. 152, 879-884.

Bae, E.-J., Lee, H.-J., Rockenstein, E., Ho, D.-H., Park, E.-B., Yang, N.-Y., Desplats, P., Masliah, E., Lee, S.-J., 2012. Antibody-aided clearance of extracellular $\alpha$-synuclein prevents cell-to-cell aggregate transmission. J. Neurosci. Off. J. Soc. Neurosci. 32, 13454-13469. https://doi.org/10.1523/JNEUROSCI.1292-12.2012

Bernis, M.E., Babila, J.T., Breid, S., Wüsten, K.A., Wüllner, U., Tamgüney, G., 2015. Prion-like propagation of human brain-derived alpha-synuclein in transgenic mice expressing human wild-type alphasynuclein. Acta Neuropathol. Commun. 3, 75. https://doi.org/10.1186/s40478-015-0254-7

Bliederhaeuser, C., Grozdanov, V., Speidel, A., Zondler, L., Ruf, W.P., Bayer, H., Kiechle, M., Feiler, M.S., Freischmidt, A., Brenner, D., Witting, A., Hengerer, B., Fändrich, M., Ludolph, A.C., Weishaupt, J.H., Gillardon, F., Danzer, K.M., 2016. Age-dependent defects of alpha-synuclein oligomer uptake in microglia and monocytes. Acta Neuropathol. (Berl.) 131, 379-391. https://doi.org/10.1007/s00401015-1504-2

Bousset, L., Pieri, L., Ruiz-Arlandis, G., Gath, J., Jensen, P.H., Habenstein, B., Madiona, K., Olieric, V., Böckmann, A., Meier, B.H., Melki, R., 2013. Structural and functional characterization of two alphasynuclein strains. Nat. Commun. 4, 2575. https://doi.org/10.1038/ncomms3575

Braak, H., de Vos, R.A.I., Bohl, J., Del Tredici, K., 2006. Gastric alpha-synuclein immunoreactive inclusions in Meissner's and Auerbach's plexuses in cases staged for Parkinson's disease-related brain pathology. Neurosci. Lett. 396, 67-72. https://doi.org/10.1016/j.neulet.2005.11.012

Braak, H., Del Tredici, K., Rüb, U., de Vos, R.A.I., Jansen Steur, E.N.H., Braak, E., 2003. Staging of brain pathology related to sporadic Parkinson's disease. Neurobiol. Aging 24, 197-211.

Brahic, M., Bousset, L., Bieri, G., Melki, R., Gitler, A.D., 2016. Axonal transport and secretion of fibrillar forms of $\alpha$-synuclein, A 442 peptide and HTTExon 1. Acta Neuropathol. (Berl.) 131, 539-548. https://doi.org/10.1007/s00401-016-1538-0

Bruce, M.E., 1993. Scrapie strain variation and mutation. Br. Med. Bull. 49, 822-838.

Brundin, P., Melki, R., 2017. Prying into the Prion Hypothesis for Parkinson's Disease. J. Neurosci. Off. J. Soc. Neurosci. 37, 9808-9818. https://doi.org/10.1523/JNEUROSCI.1788-16.2017

Choi, D.C., Yoo, M., Kabaria, S., Junn, E., 2018. MicroRNA-7 facilitates the degradation of alpha-synuclein and its aggregates by promoting autophagy. Neurosci. Lett. 678, 118-123. https://doi.org/10.1016/j.neulet.2018.05.009

Chu, Y., Kordower, J.H., 2007. Age-associated increases of alpha-synuclein in monkeys and humans are associated with nigrostriatal dopamine depletion: Is this the target for Parkinson's disease? Neurobiol. Dis. 25, 134-149. https://doi.org/10.1016/j.nbd.2006.08.021

Collier, T.J., Kanaan, N.M., Kordower, J.H., 2017. Aging and Parkinson's disease: Different sides of the same coin? Mov. Disord. Off. J. Mov. Disord. Soc. 32, 983-990. https://doi.org/10.1002/mds.27037

Colombo, M., Raposo, G., Théry, C., 2014. Biogenesis, secretion, and intercellular interactions of exosomes and other extracellular vesicles. Annu. Rev. Cell Dev. Biol. 30, 255-289. https://doi.org/10.1146/annurev-cellbio-101512-122326

Conway, K.A., Harper, J.D., Lansbury, P.T., 1998. Accelerated in vitro fibril formation by a mutant alphasynuclein linked to early-onset Parkinson disease. Nat. Med. 4, 1318-1320. https://doi.org/10.1038/3311

Conway, K.A., Rochet, J.C., Bieganski, R.M., Lansbury, P.T., 2001. Kinetic stabilization of the alpha-synuclein protofibril by a dopamine-alpha-synuclein adduct. Science 294, 1346-1349. https://doi.org/10.1126/science.1063522

Crews, L., Spencer, B., Desplats, P., Patrick, C., Paulino, A., Rockenstein, E., Hansen, L., Adame, A., Galasko, D., Masliah, E., 2010. Selective molecular alterations in the autophagy pathway in patients with 
Lewy body disease and in models of alpha-synucleinopathy. PloS One 5, e9313.

https://doi.org/10.1371/journal.pone.0009313

Danzer, K.M., Kranich, L.R., Ruf, W.P., Cagsal-Getkin, O., Winslow, A.R., Zhu, L., Vanderburg, C.R., McLean, P.J., 2012. Exosomal cell-to-cell transmission of alpha synuclein oligomers. Mol. Neurodegener. 7, 42. https://doi.org/10.1186/1750-1326-7-42

Danzer, K.M., Ruf, W.P., Putcha, P., Joyner, D., Hashimoto, T., Glabe, C., Hyman, B.T., McLean, P.J., 2011. Heat-shock protein 70 modulates toxic extracellular $\alpha$-synuclein oligomers and rescues transsynaptic toxicity. FASEB J. Off. Publ. Fed. Am. Soc. Exp. Biol. 25, 326-336. https://doi.org/10.1096/fj.10-164624

Davis, A.A., Leyns, C.E.G., Holtzman, D.M., 2018. Intercellular Spread of Protein Aggregates in Neurodegenerative Disease. Annu. Rev. Cell Dev. Biol. https://doi.org/10.1146/annurev-cellbio100617-062636

Del Tredici, K., Braak, H., 2016. Review: Sporadic Parkinson's disease: development and distribution of $\alpha-$ synuclein pathology. Neuropathol. Appl. Neurobiol. 42, 33-50. https://doi.org/10.1111/nan.12298

Delenclos, M., Trendafilova, T., Mahesh, D., Baine, A.M., Moussaud, S., Yan, I.K., Patel, T., McLean, P.J., 2017. Investigation of Endocytic Pathways for the Internalization of Exosome-Associated Oligomeric Alpha-Synuclein. Front. Neurosci. 11, 172. https://doi.org/10.3389/fnins.2017.00172

Desplats, P., Lee, H.-J., Bae, E.-J., Patrick, C., Rockenstein, E., Crews, L., Spencer, B., Masliah, E., Lee, S.-J., 2009. Inclusion formation and neuronal cell death through neuron-to-neuron transmission of alpha-synuclein. Proc. Natl. Acad. Sci. U. S. A. 106, 13010-13015. https://doi.org/10.1073/pnas.0903691106

Devic, I., Hwang, H., Edgar, J.S., Izutsu, K., Presland, R., Pan, C., Goodlett, D.R., Wang, Y., Armaly, J., Tumas, V., Zabetian, C.P., Leverenz, J.B., Shi, M., Zhang, J., 2011. Salivary $\alpha$-synuclein and DJ-1: potential biomarkers for Parkinson's disease. Brain J. Neurol. 134, e178. https://doi.org/10.1093/brain/awr015

Dieriks, B.V., Park, T.I.-H., Fourie, C., Faull, R.L.M., Dragunow, M., Curtis, M.A., 2017. $\alpha$-synuclein transfer through tunneling nanotubes occurs in SH-SY5Y cells and primary brain pericytes from Parkinson's disease patients. Sci. Rep. 7, 42984. https://doi.org/10.1038/srep42984

Doty, R.L., 2012. Olfactory dysfunction in Parkinson disease. Nat. Rev. Neurol. 8, 329-339. https://doi.org/10.1038/nrneurol.2012.80

Ejlerskov, P., Rasmussen, I., Nielsen, T.T., Bergström, A.-L., Tohyama, Y., Jensen, P.H., Vilhardt, F., 2013. Tubulin polymerization-promoting protein (TPPP/p25 $\alpha$ ) promotes unconventional secretion of $\alpha$ synuclein through exophagy by impairing autophagosome-lysosome fusion. J. Biol. Chem. 288, 17313-17335. https://doi.org/10.1074/jbc.M112.401174

El-Agnaf, O.M.A., Salem, S.A., Paleologou, K.E., Cooper, L.J., Fullwood, N.J., Gibson, M.J., Curran, M.D., Court, J.A., Mann, D.M.A., Ikeda, S., Cookson, M.R., Hardy, J., Allsop, D., 2003. Alpha-synuclein implicated in Parkinson's disease is present in extracellular biological fluids, including human plasma. FASEB J. Off. Publ. Fed. Am. Soc. Exp. Biol. 17, 1945-1947. https://doi.org/10.1096/fj.030098fje

El-Agnaf, O.M.A., Salem, S.A., Paleologou, K.E., Curran, M.D., Gibson, M.J., Court, J.A., Schlossmacher, M.G., Allsop, D., 2006. Detection of oligomeric forms of alpha-synuclein protein in human plasma as a potential biomarker for Parkinson's disease. FASEB J. Off. Publ. Fed. Am. Soc. Exp. Biol. 20, 419425. https://doi.org/10.1096/fj.03-1449com

Emmanouilidou, E., Melachroinou, K., Roumeliotis, T., Garbis, S.D., Ntzouni, M., Margaritis, L.H., Stefanis, L., Vekrellis, K., 2010. Cell-produced alpha-synuclein is secreted in a calcium-dependent manner by exosomes and impacts neuronal survival. J. Neurosci. Off. J. Soc. Neurosci. 30, 6838-6851. https://doi.org/10.1523/JNEUROSCI.5699-09.2010

Emmanouilidou, E., Minakaki, G., Keramioti, M.V., Xylaki, M., Balafas, E., Chrysanthou-Piterou, M., Kloukina, I., Vekrellis, K., 2016. GABA transmission via ATP-dependent $\mathrm{K}+$ channels regulates $\alpha$-synuclein secretion in mouse striatum. Brain J. Neurol. 139, 871-890. https://doi.org/10.1093/brain/awv403

Fauré, J., Lachenal, G., Court, M., Hirrlinger, J., Chatellard-Causse, C., Blot, B., Grange, J., Schoehn, G., Goldberg, Y., Boyer, V., Kirchhoff, F., Raposo, G., Garin, J., Sadoul, R., 2006. Exosomes are released 
by cultured cortical neurones. Mol. Cell. Neurosci. 31, 642-648.

https://doi.org/10.1016/j.mcn.2005.12.003

Feng, D., Zhao, W.-L., Ye, Y.-Y., Bai, X.-C., Liu, R.-Q., Chang, L.-F., Zhou, Q., Sui, S.-F., 2010. Cellular internalization of exosomes occurs through phagocytosis. Traffic Cph. Den. 11, 675-687. https://doi.org/10.1111/j.1600-0854.2010.01041.x

Fereshtehnejad, S.-M., Postuma, R.B., 2017. Subtypes of Parkinson's Disease: What Do They Tell Us About Disease Progression? Curr. Neurol. Neurosci. Rep. 17, 34. https://doi.org/10.1007/s11910-0170738-x

Fortin, D.L., Troyer, M.D., Nakamura, K., Kubo, S., Anthony, M.D., Edwards, R.H., 2004. Lipid rafts mediate the synaptic localization of alpha-synuclein. J. Neurosci. Off. J. Soc. Neurosci. 24, 6715-6723. https://doi.org/10.1523/JNEUROSCI.1594-04.2004

Freundt, E.C., Maynard, N., Clancy, E.K., Roy, S., Bousset, L., Sourigues, Y., Covert, M., Melki, R., Kirkegaard, K., Brahic, M., 2012. Neuron-to-neuron transmission of $\alpha$-synuclein fibrils through axonal transport. Ann. Neurol. 72, 517-524. https://doi.org/10.1002/ana.23747

Gelpi, E., Navarro-Otano, J., Tolosa, E., Gaig, C., Compta, Y., Rey, M.J., Martí, M.J., Hernández, I., Valldeoriola, F., Reñé, R., Ribalta, T., 2014. Multiple organ involvement by alpha-synuclein pathology in Lewy body disorders. Mov. Disord. Off. J. Mov. Disord. Soc. 29, 1010-1018. https://doi.org/10.1002/mds.25776

Gerdes, H.-H., Rustom, A., Wang, X., 2013. Tunneling nanotubes, an emerging intercellular communication route in development. Mech. Dev. 130, 381-387. https://doi.org/10.1016/j.mod.2012.11.006

Halliday, G.M., Holton, J.L., Revesz, T., Dickson, D.W., 2011. Neuropathology underlying clinical variability in patients with synucleinopathies. Acta Neuropathol. (Berl.) 122, 187-204. https://doi.org/10.1007/s00401-011-0852-9

Hansen, C., Angot, E., Bergström, A.-L., Steiner, J.A., Pieri, L., Paul, G., Outeiro, T.F., Melki, R., Kallunki, P., Fog, K., Li, J.-Y., Brundin, P., 2011. $\alpha$-Synuclein propagates from mouse brain to grafted dopaminergic neurons and seeds aggregation in cultured human cells. J. Clin. Invest. 121, 715-725. https://doi.org/10.1172/JCl43366

Holmes, B.B., DeVos, S.L., Kfoury, N., Li, M., Jacks, R., Yanamandra, K., Ouidja, M.O., Brodsky, F.M., Marasa, J., Bagchi, D.P., Kotzbauer, P.T., Miller, T.M., Papy-Garcia, D., Diamond, M.I., 2013. Heparan sulfate proteoglycans mediate internalization and propagation of specific proteopathic seeds. Proc. Natl. Acad. Sci. U. S. A. 110, E3138-3147. https://doi.org/10.1073/pnas.1301440110

Holmqvist, S., Chutna, O., Bousset, L., Aldrin-Kirk, P., Li, W., Björklund, T., Wang, Z.-Y., Roybon, L., Melki, R., Li, J.-Y., 2014. Direct evidence of Parkinson pathology spread from the gastrointestinal tract to the brain in rats. Acta Neuropathol. (Berl.) 128, 805-820. https://doi.org/10.1007/s00401-014-1343-6

Jang, A., Lee, H.-J., Suk, J.-E., Jung, J.-W., Kim, K.-P., Lee, S.-J., 2010. Non-classical exocytosis of alphasynuclein is sensitive to folding states and promoted under stress conditions. J. Neurochem. 113, 1263-1274. https://doi.org/10.1111/j.1471-4159.2010.06695.x

Jucker, M., Walker, L.C., 2018. Propagation and spread of pathogenic protein assemblies in neurodegenerative diseases. Nat. Neurosci. 21, 1341-1349. https://doi.org/10.1038/s41593-0180238-6

Kempster, P.A., O'Sullivan, S.S., Holton, J.L., Revesz, T., Lees, A.J., 2010. Relationships between age and late progression of Parkinson's disease: a clinico-pathological study. Brain J. Neurol. 133, 1755-1762. https://doi.org/10.1093/brain/awq059

Khodr, C.E., Becerra, A., Han, Y., Bohn, M.C., 2014. Targeting alpha-synuclein with a microRNA-embedded silencing vector in the rat substantia nigra: positive and negative effects. Brain Res. 1550, 47-60. https://doi.org/10.1016/j.brainres.2014.01.010

Kisielow, M., Kisielow, J., Capoferri-Sollami, G., Karjalainen, K., 2005. Expression of lymphocyte activation gene 3 (LAG-3) on B cells is induced by T cells. Eur. J. Immunol. 35, 2081-2088. https://doi.org/10.1002/eji.200526090

Kordower, J.H., Chu, Y., Hauser, R.A., Freeman, T.B., Olanow, C.W., 2008. Lewy body-like pathology in longterm embryonic nigral transplants in Parkinson's disease. Nat. Med. 14, 504-506.

https://doi.org/10.1038/nm1747 
Kordower, J.H., Dodiya, H.B., Kordower, A.M., Terpstra, B., Paumier, K., Madhavan, L., Sortwell, C., SteeceCollier, K., Collier, T.J., 2011. Transfer of host-derived a synuclein to grafted dopaminergic neurons in rat. Neurobiol. Dis. 43, 552-557. https://doi.org/10.1016/j.nbd.2011.05.001

Krammer, C., Schätzl, H.M., Vorberg, I., 2009. Prion-like propagation of cytosolic protein aggregates: insights from cell culture models. Prion 3, 206-212.

Lee, H.-J., Patel, S., Lee, S.-J., 2005. Intravesicular localization and exocytosis of alpha-synuclein and its aggregates. J. Neurosci. Off. J. Soc. Neurosci. 25, 6016-6024. https://doi.org/10.1523/JNEUROSCI.0692-05.2005

Lee, H.-J., Suk, J.-E., Bae, E.-J., Lee, J.-H., Paik, S.R., Lee, S.-J., 2008. Assembly-dependent endocytosis and clearance of extracellular alpha-synuclein. Int. J. Biochem. Cell Biol. 40, 1835-1849. https://doi.org/10.1016/j.biocel.2008.01.017

Lee, H.-J., Suk, J.-E., Patrick, C., Bae, E.-J., Cho, J.-H., Rho, S., Hwang, D., Masliah, E., Lee, S.-J., 2010. Direct transfer of alpha-synuclein from neuron to astroglia causes inflammatory responses in synucleinopathies. J. Biol. Chem. 285, 9262-9272. https://doi.org/10.1074/jbc.M109.081125

Li, J.-Y., Englund, E., Holton, J.L., Soulet, D., Hagell, P., Lees, A.J., Lashley, T., Quinn, N.P., Rehncrona, S., Björklund, A., Widner, H., Revesz, T., Lindvall, O., Brundin, P., 2008. Lewy bodies in grafted neurons in subjects with Parkinson's disease suggest host-to-graft disease propagation. Nat. Med. 14, 501503. https://doi.org/10.1038/nm1746

Li, W., Lesuisse, C., Xu, Y., Troncoso, J.C., Price, D.L., Lee, M.K., 2004. Stabilization of alpha-synuclein protein with aging and familial parkinson's disease-linked A53T mutation. J. Neurosci. Off. J. Soc. Neurosci. 24, 7400-7409. https://doi.org/10.1523/JNEUROSCI.1370-04.2004

Lippa, C.F., Fujiwara, H., Mann, D.M., Giasson, B., Baba, M., Schmidt, M.L., Nee, L.E., O'Connell, B., Pollen, D.A., St George-Hyslop, P., Ghetti, B., Nochlin, D., Bird, T.D., Cairns, N.J., Lee, V.M., Iwatsubo, T., Trojanowski, J.Q., 1998. Lewy bodies contain altered alpha-synuclein in brains of many familial Alzheimer's disease patients with mutations in presenilin and amyloid precursor protein genes. Am. J. Pathol. 153, 1365-1370.

Liu, J., Zhou, Y., Wang, Y., Fong, H., Murray, T.M., Zhang, J., 2007. Identification of proteins involved in microglial endocytosis of alpha-synuclein. J. Proteome Res. 6, 3614-3627. https://doi.org/10.1021/pr0701512

Liu, Y., Sorce, S., Nuvolone, M., Domange, J., Aguzzi, A., 2018. Lymphocyte activation gene 3 (Lag3) expression is increased in prion infections but does not modify disease progression. Sci. Rep. 8, 14600. https://doi.org/10.1038/s41598-018-32712-8

Loria, F., Vargas, J.Y., Bousset, L., Syan, S., Salles, A., Melki, R., Zurzolo, C., 2017. $\alpha$-Synuclein transfer between neurons and astrocytes indicates that astrocytes play a role in degradation rather than in spreading. Acta Neuropathol. (Berl.) 134, 789-808. https://doi.org/10.1007/s00401-017-1746-2

Luk, K.C., Covell, D.J., Kehm, V.M., Zhang, B., Song, I.Y., Byrne, M.D., Pitkin, R.M., Decker, S.C., Trojanowski, J.Q., Lee, V.M.-Y., 2016. Molecular and Biological Compatibility with Host Alpha-Synuclein Influences Fibril Pathogenicity. Cell Rep. 16, 3373-3387. https://doi.org/10.1016/j.celrep.2016.08.053

Luk, K.C., Kehm, V., Carroll, J., Zhang, B., O'Brien, P., Trojanowski, J.Q., Lee, V.M.-Y., 2012a. Pathological $\alpha-$ synuclein transmission initiates Parkinson-like neurodegeneration in nontransgenic mice. Science 338, 949-953. https://doi.org/10.1126/science.1227157

Luk, K.C., Kehm, V.M., Zhang, B., O'Brien, P., Trojanowski, J.Q., Lee, V.M.Y., 2012b. Intracerebral inoculation of pathological $\alpha$-synuclein initiates a rapidly progressive neurodegenerative $\alpha$-synucleinopathy in mice. J. Exp. Med. 209, 975-986. https://doi.org/10.1084/jem.20112457

Luk, K.C., Song, C., O’Brien, P., Stieber, A., Branch, J.R., Brunden, K.R., Trojanowski, J.Q., Lee, V.M.-Y., 2009. Exogenous alpha-synuclein fibrils seed the formation of Lewy body-like intracellular inclusions in cultured cells. Proc. Natl. Acad. Sci. U. S. A. 106, 20051-20056. https://doi.org/10.1073/pnas.0908005106

Makin, S., 2016. Pathology: The prion principle. Nature 538, S13-S16. https://doi.org/10.1038/538S13a Mandler, M., Valera, E., Rockenstein, E., Weninger, H., Patrick, C., Adame, A., Santic, R., Meindl, S., Vigl, B., Smrzka, O., Schneeberger, A., Mattner, F., Masliah, E., 2014. Next-generation active immunization 
approach for synucleinopathies: implications for Parkinson's disease clinical trials. Acta

Neuropathol. (Berl.) 127, 861-879. https://doi.org/10.1007/s00401-014-1256-4

Manfredsson, F.P., Luk, K.C., Benskey, M.J., Gezer, A., Garcia, J., Kuhn, N.C., Sandoval, I.M., Patterson, J.R., O'Mara, A., Yonkers, R., Kordower, J.H., 2018. Induction of alpha-synuclein pathology in the enteric nervous system of the rat and non-human primate results in gastrointestinal dysmotility and transient CNS pathology. Neurobiol. Dis. 112, 106-118. https://doi.org/10.1016/j.nbd.2018.01.008

Mao, X., Ou, M.T., Karuppagounder, S.S., Kam, T.-I., Yin, X., Xiong, Y., Ge, P., Umanah, G.E., Brahmachari, S., Shin, J.-H., Kang, H.C., Zhang, J., Xu, J., Chen, R., Park, H., Andrabi, S.A., Kang, S.U., Gonçalves, R.A., Liang, Y., Zhang, S., Qi, C., Lam, S., Keiler, J.A., Tyson, J., Kim, D., Panicker, N., Yun, S.P., Workman, C.J., Vignali, D.A.A., Dawson, V.L., Ko, H.S., Dawson, T.M., 2016. Pathological $\alpha$-synuclein transmission initiated by binding lymphocyte-activation gene 3. Science 353. https://doi.org/10.1126/science.aah3374

Masliah, E., Rockenstein, E., Adame, A., Alford, M., Crews, L., Hashimoto, M., Seubert, P., Lee, M., Goldstein, J., Chilcote, T., Games, D., Schenk, D., 2005. Effects of alpha-synuclein immunization in a mouse model of Parkinson's disease. Neuron 46, 857-868.

https://doi.org/10.1016/j.neuron.2005.05.010

Mason, D.M., Nouraei, N., Pant, D.B., Miner, K.M., Hutchison, D.F., Luk, K.C., Stolz, J.F., Leak, R.K., 2016. Transmission of $\alpha$-synucleinopathy from olfactory structures deep into the temporal lobe. Mol. Neurodegener. 11, 49. https://doi.org/10.1186/s13024-016-0113-4

Masuda-Suzukake, M., Nonaka, T., Hosokawa, M., Kubo, M., Shimozawa, A., Akiyama, H., Hasegawa, M., 2014. Pathological alpha-synuclein propagates through neural networks. Acta Neuropathol. Commun. 2, 88. https://doi.org/10.1186/PREACCEPT-1296467154135944

Masuda-Suzukake, M., Nonaka, T., Hosokawa, M., Oikawa, T., Arai, T., Akiyama, H., Mann, D.M.A., Hasegawa, M., 2013. Prion-like spreading of pathological $\alpha$-synuclein in brain. Brain J. Neurol. 136, 1128-1138. https://doi.org/10.1093/brain/awt037

Matsumoto, J., Stewart, T., Sheng, L., Li, N., Bullock, K., Song, N., Shi, M., Banks, W.A., Zhang, J., 2017. Transmission of $\alpha$-synuclein-containing erythrocyte-derived extracellular vesicles across the bloodbrain barrier via adsorptive mediated transcytosis: another mechanism for initiation and progression of Parkinson's disease? Acta Neuropathol. Commun. 5, 71. https://doi.org/10.1186/s40478-017-0470-4

McCann, H., Stevens, C.H., Cartwright, H., Halliday, G.M., 2014. $\alpha$-Synucleinopathy phenotypes. Parkinsonism Relat. Disord. 20 Suppl 1, S62-67. https://doi.org/10.1016/S1353-8020(13)70017-8

Mitsuhashi, M., Taub, D.D., Kapogiannis, D., Eitan, E., Zukley, L., Mattson, M.P., Ferrucci, L., Schwartz, J.B., Goetzl, E.J., 2013. Aging enhances release of exosomal cytokine mRNAs by Aß1-42-stimulated macrophages. FASEB J. 27, 5141-5150. https://doi.org/10.1096/fj.13-238980

Mollenhauer, B., Cullen, V., Kahn, I., Krastins, B., Outeiro, T.F., Pepivani, I., Ng, J., Schulz-Schaeffer, W., Kretzschmar, H.A., McLean, P.J., Trenkwalder, C., Sarracino, D.A., Vonsattel, J.-P., Locascio, J.J., ElAgnaf, O.M.A., Schlossmacher, M.G., 2008. Direct quantification of CSF alpha-synuclein by ELISA and first cross-sectional study in patients with neurodegeneration. Exp. Neurol. 213, 315-325. https://doi.org/10.1016/j.expneurol.2008.06.004

Mougenot, A.-L., Nicot, S., Bencsik, A., Morignat, E., Verchère, J., Lakhdar, L., Legastelois, S., Baron, T., 2012. Prion-like acceleration of a synucleinopathy in a transgenic mouse model. Neurobiol. Aging 33, 2225-2228. https://doi.org/10.1016/j.neurobiolaging.2011.06.022

Mulak, A., Bonaz, B., 2015. Brain-gut-microbiota axis in Parkinson's disease. World J. Gastroenterol. 21, 10609-10620. https://doi.org/10.3748/wjg.v21.i37.10609

Mulcahy, L.A., Pink, R.C., Carter, D.R.F., 2014. Routes and mechanisms of extracellular vesicle uptake. J. Extracell. Vesicles 3. https://doi.org/10.3402/jev.v3.24641

Olive, S., Rougon, G., Pierre, K., Theodosis, D.T., 1995. Expression of a glycosyl phosphatidylinositolanchored adhesion molecule, the glycoprotein $\mathrm{F} 3$, in the adult rat hypothalamo-neurohypophysial system. Brain Res. 689, 271-280. 
Osterberg, V.R., Spinelli, K.J., Weston, L.J., Luk, K.C., Woltjer, R.L., Unni, V.K., 2015. Progressive aggregation of alpha-synuclein and selective degeneration of lewy inclusion-bearing neurons in a mouse model of parkinsonism. Cell Rep. 10, 1252-1260. https://doi.org/10.1016/j.celrep.2015.01.060

Pagano, G., Ferrara, N., Brooks, D.J., Pavese, N., 2016. Age at onset and Parkinson disease phenotype. Neurology 86, 1400-1407. https://doi.org/10.1212/WNL.0000000000002461

Paumier, K.L., Luk, K.C., Manfredsson, F.P., Kanaan, N.M., Lipton, J.W., Collier, T.J., Steece-Collier, K., Kemp, C.J., Celano, S., Schulz, E., Sandoval, I.M., Fleming, S., Dirr, E., Polinski, N.K., Trojanowski, J.Q., Lee, V.M., Sortwell, C.E., 2015. Intrastriatal injection of pre-formed mouse $\alpha$-synuclein fibrils into rats triggers $\alpha$-synuclein pathology and bilateral nigrostriatal degeneration. Neurobiol. Dis. 82, 185-199. https://doi.org/10.1016/j.nbd.2015.06.003

Peelaerts, W., Bousset, L., Van der Perren, A., Moskalyuk, A., Pulizzi, R., Giugliano, M., Van den Haute, C., Melki, R., Baekelandt, V., 2015. $\alpha$-Synuclein strains cause distinct synucleinopathies after local and systemic administration. Nature 522, 340-344. https://doi.org/10.1038/nature14547

Pieri, L., Madiona, K., Bousset, L., Melki, R., 2012. Fibrillar $\alpha$-synuclein and huntingtin exon 1 assemblies are toxic to the cells. Biophys. J. 102, 2894-2905. https://doi.org/10.1016/j.bpj.2012.04.050

Pieri, L., Madiona, K., Melki, R., 2016. Structural and functional properties of prefibrillar $\alpha$-synuclein oligomers. Sci. Rep. 6, 24526. https://doi.org/10.1038/srep24526

Poewe, W., Seppi, K., Tanner, C.M., Halliday, G.M., Brundin, P., Volkmann, J., Schrag, A.-E., Lang, A.E., 2017. Parkinson disease. Nat. Rev. Dis. Primer 3, 17013. https://doi.org/10.1038/nrdp.2017.13

Prusiner, S.B., 1991. Molecular biology of prion diseases. Science 252, 1515-1522.

Rahman, M.A., Rhim, H., 2017. Therapeutic implication of autophagy in neurodegenerative diseases. BMB Rep. 50, 345-354. https://doi.org/10.5483/BMBRep.2017.50.7.069

Recasens, A., Dehay, B., Bové, J., Carballo-Carbajal, I., Dovero, S., Pérez-Villalba, A., Fernagut, P.-O., Blesa, J., Parent, A., Perier, C., Fariñas, I., Obeso, J.A., Bezard, E., Vila, M., 2014. Lewy body extracts from Parkinson disease brains trigger $\alpha$-synuclein pathology and neurodegeneration in mice and monkeys. Ann. Neurol. 75, 351-362. https://doi.org/10.1002/ana.24066

Rey, N.L., George, S., Steiner, J.A., Madaj, Z., Luk, K.C., Trojanowski, J.Q., Lee, V.M.-Y., Brundin, P., 2018. Spread of aggregates after olfactory bulb injection of $\alpha$-synuclein fibrils is associated with early neuronal loss and is reduced long term. Acta Neuropathol. (Berl.) 135, 65-83.

https://doi.org/10.1007/s00401-017-1792-9

Rey, N.L., Petit, G.H., Bousset, L., Melki, R., Brundin, P., 2013. Transfer of human $\alpha$-synuclein from the olfactory bulb to interconnected brain regions in mice. Acta Neuropathol. (Berl.) 126, 555-573. https://doi.org/10.1007/s00401-013-1160-3

Rey, N.L., Steiner, J.A., Maroof, N., Luk, K.C., Madaj, Z., Trojanowski, J.Q., Lee, V.M.-Y., Brundin, P., 2016. Widespread transneuronal propagation of $\alpha$-synucleinopathy triggered in olfactory bulb mimics prodromal Parkinson's disease. J. Exp. Med. 213, 1759-1778. https://doi.org/10.1084/jem.20160368

Reyes, J.F., Olsson, T.T., Lamberts, J.T., Devine, M.J., Kunath, T., Brundin, P., 2015. A cell culture model for monitoring $\alpha$-synuclein cell-to-cell transfer. Neurobiol. Dis. 77, 266-275. https://doi.org/10.1016/j.nbd.2014.07.003

Reyes, J.F., Rey, N.L., Bousset, L., Melki, R., Brundin, P., Angot, E., 2014. Alpha-synuclein transfers from neurons to oligodendrocytes. Glia 62, 387-398. https://doi.org/10.1002/glia.22611

Rostami, J., Holmqvist, S., Lindström, V., Sigvardson, J., Westermark, G.T., Ingelsson, M., Bergström, J., Roybon, L., Erlandsson, A., 2017. Human Astrocytes Transfer Aggregated Alpha-Synuclein via Tunneling Nanotubes. J. Neurosci. Off. J. Soc. Neurosci. 37, 11835-11853. https://doi.org/10.1523/JNEUROSCI.0983-17.2017

Ruffmann, C., Bengoa-Vergniory, N., Poggiolini, I., Ritchie, D., Hu, M.T., Alegre-Abarrategui, J., Parkkinen, L., 2018. Detection of alpha-synuclein conformational variants from gastro-intestinal biopsy tissue as a potential biomarker for Parkinson's disease. Neuropathol. Appl. Neurobiol. https://doi.org/10.1111/nan.12486

Sacino, A.N., Brooks, M., McKinney, A.B., Thomas, M.A., Shaw, G., Golde, T.E., Giasson, B.I., 2014a. Brain injection of $\alpha$-synuclein induces multiple proteinopathies, gliosis, and a neuronal injury marker. J. 
Neurosci. Off. J. Soc. Neurosci. 34, 12368-12378. https://doi.org/10.1523/JNEUROSCl.210214.2014

Sacino, A.N., Brooks, M., Thomas, M.A., McKinney, A.B., Lee, S., Regenhardt, R.W., McGarvey, N.H., Ayers, J.I., Notterpek, L., Borchelt, D.R., Golde, T.E., Giasson, B.I., 2014b. Intramuscular injection of $\alpha$ synuclein induces CNS $\alpha$-synuclein pathology and a rapid-onset motor phenotype in transgenic mice. Proc. Natl. Acad. Sci. U. S. A. 111, 10732-10737. https://doi.org/10.1073/pnas.1321785111

Sampson, T.R., Debelius, J.W., Thron, T., Janssen, S., Shastri, G.G., Ilhan, Z.E., Challis, C., Schretter, C.E., Rocha, S., Gradinaru, V., Chesselet, M.-F., Keshavarzian, A., Shannon, K.M., Krajmalnik-Brown, R., Wittung-Stafshede, P., Knight, R., Mazmanian, S.K., 2016. Gut Microbiota Regulate Motor Deficits and Neuroinflammation in a Model of Parkinson's Disease. Cell 167, 1469-1480.e12. https://doi.org/10.1016/j.cell.2016.11.018

Shaltiel-Karyo, R., Frenkel-Pinter, M., Rockenstein, E., Patrick, C., Levy-Sakin, M., Schiller, A., Egoz-Matia, N., Masliah, E., Segal, D., Gazit, E., 2013. A blood-brain barrier (BBB) disrupter is also a potent $\alpha$ synuclein ( $\alpha$-syn) aggregation inhibitor: a novel dual mechanism of mannitol for the treatment of Parkinson disease (PD). J. Biol. Chem. 288, 17579-17588.

https://doi.org/10.1074/jbc.M112.434787

Shimozawa, A., Ono, M., Takahara, D., Tarutani, A., Imura, S., Masuda-Suzukake, M., Higuchi, M., Yanai, K., Hisanaga, S.-I., Hasegawa, M., 2017. Propagation of pathological $\alpha$-synuclein in marmoset brain. Acta Neuropathol. Commun. 5, 12. https://doi.org/10.1186/s40478-017-0413-0

Shrivastava, A.N., Redeker, V., Fritz, N., Pieri, L., Almeida, L.G., Spolidoro, M., Liebmann, T., Bousset, L., Renner, M., Léna, C., Aperia, A., Melki, R., Triller, A., 2015. $\alpha$-synuclein assemblies sequester neuronal $\alpha 3-\mathrm{Na}+/ \mathrm{K}+-\mathrm{ATPase}$ and impair $\mathrm{Na}+$ gradient. EMBO J. 34, 2408-2423. https://doi.org/10.15252/embj.201591397

Sorrentino, Z.A., Brooks, M.M.T., Hudson, V., Rutherford, N.J., Golde, T.E., Giasson, B.I., Chakrabarty, P., 2017. Intrastriatal injection of $\alpha$-synuclein can lead to widespread synucleinopathy independent of neuroanatomic connectivity. Mol. Neurodegener. 12, 40. https://doi.org/10.1186/s13024-0170182-z

Spencer, B., Valera, E., Rockenstein, E., Overk, C., Mante, M., Adame, A., Zago, W., Seubert, P., Barbour, R., Schenk, D., Games, D., Rissman, R.A., Masliah, E., 2017. Anti- $\alpha$-synuclein immunotherapy reduces $\alpha$-synuclein propagation in the axon and degeneration in a combined viral vector and transgenic model of synucleinopathy. Acta Neuropathol. Commun. 5, 7. https://doi.org/10.1186/s40478-0160410-8

Stuendl, A., Kunadt, M., Kruse, N., Bartels, C., Moebius, W., Danzer, K.M., Mollenhauer, B., Schneider, A., 2016. Induction of $\alpha$-synuclein aggregate formation by CSF exosomes from patients with Parkinson's disease and dementia with Lewy bodies. Brain J. Neurol. 139, 481-494. https://doi.org/10.1093/brain/awv346

Surmeier, D.J., Obeso, J.A., Halliday, G.M., 2017. Selective neuronal vulnerability in Parkinson disease. Nat. Rev. Neurosci. 18, 101-113. https://doi.org/10.1038/nrn.2016.178

Taguchi, K., Watanabe, Y., Tsujimura, A., Tanaka, M., 2016. Brain region-dependent differential expression of alpha-synuclein. J. Comp. Neurol. 524, 1236-1258. https://doi.org/10.1002/cne.23901

Takamatsu, Y., Fujita, M., Ho, G.J., Wada, R., Sugama, S., Takenouchi, T., Waragai, M., Masliah, E., Hashimoto, M., 2018. Motor and Nonmotor Symptoms of Parkinson's Disease: Antagonistic Pleiotropy Phenomena Derived from $\alpha$-Synuclein Evolvability? Park. Dis. 2018, 5789424. https://doi.org/10.1155/2018/5789424

Taschenberger, G., Garrido, M., Tereshchenko, Y., Bähr, M., Zweckstetter, M., Kügler, S., 2012. Aggregation of $\alpha$ Synuclein promotes progressive in vivo neurotoxicity in adult rat dopaminergic neurons. Acta Neuropathol. (Berl.) 123, 671-683. https://doi.org/10.1007/s00401-011-0926-8

Tran, H.T., Chung, C.H.-Y., Iba, M., Zhang, B., Trojanowski, J.Q., Luk, K.C., Lee, V.M.Y., 2014. A-synuclein immunotherapy blocks uptake and templated propagation of misfolded $\alpha$-synuclein and neurodegeneration. Cell Rep. 7, 2054-2065. https://doi.org/10.1016/j.celrep.2014.05.033 
Triebel, F., Jitsukawa, S., Baixeras, E., Roman-Roman, S., Genevee, C., Viegas-Pequignot, E., Hercend, T., 1990. LAG-3, a novel lymphocyte activation gene closely related to CD4. J. Exp. Med. 171, 13931405.

Tsigelny, I.F., Crews, L., Desplats, P., Shaked, G.M., Sharikov, Y., Mizuno, H., Spencer, B., Rockenstein, E., Trejo, M., Platoshyn, O., Yuan, J.X.-J., Masliah, E., 2008. Mechanisms of hybrid oligomer formation in the pathogenesis of combined Alzheimer's and Parkinson's diseases. PloS One 3, e3135. https://doi.org/10.1371/journal.pone.0003135

Ulusoy, A., Musgrove, R.E., Rusconi, R., Klinkenberg, M., Helwig, M., Schneider, A., Di Monte, D.A., 2015. Neuron-to-neuron $\alpha$-synuclein propagation in vivo is independent of neuronal injury. Acta Neuropathol. Commun. 3, 13. https://doi.org/10.1186/s40478-015-0198-y

Ulusoy, A., Rusconi, R., Pérez-Revuelta, B.I., Musgrove, R.E., Helwig, M., Winzen-Reichert, B., Di Monte, D.A., 2013. Caudo-rostral brain spreading of $\alpha$-synuclein through vagal connections. EMBO Mol. Med. 5, 1119-1127. https://doi.org/10.1002/emmm.201302475

Uversky, V.N., 2007. Neuropathology, biochemistry, and biophysics of alpha-synuclein aggregation. J. Neurochem. 103, 17-37. https://doi.org/10.1111/j.1471-4159.2007.04764.x

Uversky, V.N., 2003. A protein-chameleon: conformational plasticity of alpha-synuclein, a disordered protein involved in neurodegenerative disorders. J. Biomol. Struct. Dyn. 21, 211-234. https://doi.org/10.1080/07391102.2003.10506918

Victoria, G.S., Zurzolo, C., 2017. The spread of prion-like proteins by lysosomes and tunneling nanotubes: Implications for neurodegenerative diseases. J. Cell Biol. 216, 2633-2644. https://doi.org/10.1083/jcb.201701047

Volpicelli-Daley, L.A., Luk, K.C., Patel, T.P., Tanik, S.A., Riddle, D.M., Stieber, A., Meaney, D.F., Trojanowski, J.Q., Lee, V.M.-Y., 2011. Exogenous $\alpha$-synuclein fibrils induce Lewy body pathology leading to synaptic dysfunction and neuron death. Neuron 72, 57-71. https://doi.org/10.1016/j.neuron.2011.08.033

Wang, C., Zhao, C., Li, D., Tian, Z., Lai, Y., Diao, J., Liu, C., 2016. Versatile Structures of $\alpha$-Synuclein. Front. Mol. Neurosci. 9, 48. https://doi.org/10.3389/fnmol.2016.00048

Wang, X., Yu, S., Li, F., Feng, T., 2015. Detection of $\alpha$-synuclein oligomers in red blood cells as a potential biomarker of Parkinson's disease. Neurosci. Lett. 599, 115-119. https://doi.org/10.1016/j.neulet.2015.05.030

Watts, J.C., Giles, K., Oehler, A., Middleton, L., Dexter, D.T., Gentleman, S.M., DeArmond, S.J., Prusiner, S.B., 2013. Transmission of multiple system atrophy prions to transgenic mice. Proc. Natl. Acad. Sci. U. S. A. 110, 19555-19560. https://doi.org/10.1073/pnas.1318268110

Williams, A., Sarkar, S., Cuddon, P., Ttofi, E.K., Saiki, S., Siddiqi, F.H., Jahreiss, L., Fleming, A., Pask, D., Goldsmith, P., O'Kane, C.J., Floto, R.A., Rubinsztein, D.C., 2008. Novel targets for Huntington's disease in an mTOR-independent autophagy pathway. Nat. Chem. Biol. 4, 295-305. https://doi.org/10.1038/nchembio.79

Wong, Y.C., Holzbaur, E.L.F., 2015. Autophagosome dynamics in neurodegeneration at a glance. J. Cell Sci. 128, 1259-1267. https://doi.org/10.1242/jcs.161216

Wong, Y.C., Krainc, D., 2017. $\alpha$-synuclein toxicity in neurodegeneration: mechanism and therapeutic strategies. Nat. Med. 23, 1-13. https://doi.org/10.1038/nm.4269

Workman, C.J., Rice, D.S., Dugger, K.J., Kurschner, C., Vignali, D.A.A., 2002. Phenotypic analysis of the murine CD4-related glycoprotein, CD223 (LAG-3). Eur. J. Immunol. 32, 2255-2263. https://doi.org/10.1002/1521-4141(200208)32:8<2255::AID-IMMU2255>3.0.CO;2-A

Workman, C.J., Wang, Y., Kasmi, K.C.E., Pardoll, D.M., Murray, P.J., Drake, C.G., Vignali, D.A.A., 2009. LAG-3 Regulates Plasmacytoid Dendritic Cell Homeostasis. J. Immunol. 182, 1885-1891. https://doi.org/10.4049/jimmunol.0800185

Wrasidlo, W., Tsigelny, I.F., Price, D.L., Dutta, G., Rockenstein, E., Schwarz, T.C., Ledolter, K., Bonhaus, D., Paulino, A., Eleuteri, S., Skjevik, Å.A., Kouznetsova, V.L., Spencer, B., Desplats, P., Gonzalez-Ruelas, T., Trejo-Morales, M., Overk, C.R., Winter, S., Zhu, C., Chesselet, M.-F., Meier, D., Moessler, H., Konrat, R., Masliah, E., 2016. A de novo compound targeting $\alpha$-synuclein improves deficits in 
models of Parkinson's disease. Brain J. Neurol. 139, 3217-3236.

https://doi.org/10.1093/brain/aww238

Yamada, K., Iwatsubo, T., 2018. Extracellular $\alpha$-synuclein levels are regulated by neuronal activity. Mol. Neurodegener. 13, 9. https://doi.org/10.1186/s13024-018-0241-0

Zhang, Y., Chen, K., Sloan, S.A., Bennett, M.L., Scholze, A.R., O’Keeffe, S., Phatnani, H.P., Guarnieri, P., Caneda, C., Ruderisch, N., Deng, S., Liddelow, S.A., Zhang, C., Daneman, R., Maniatis, T., Barres, B.A., Wu, J.Q., 2014. An RNA-sequencing transcriptome and splicing database of glia, neurons, and vascular cells of the cerebral cortex. J. Neurosci. Off. J. Soc. Neurosci. 34, 11929-11947.

https://doi.org/10.1523/JNEUROSCI.1860-14.2014 


\section{Figure Legends}

Figure 1. Prion-like spreading of $\alpha$-syn. A. Schematic representation of the sequential events taking place in the formation of $\alpha$-syn aggregates. Misfolding of native $\alpha$-syn gives rise to monomeric forms that are prone to aggregate. These monomers can assemble into distinct conformational states: 1 . By continuous aggregation, oligomers, protofibrils and later fibrils, are formed, 2. A high-molecular weight conformation, called ribbons, are directly assembled from monomers. Formation of $\alpha$-syn aggregates is a reversible reaction which equilibrium is displaced towards the aggregate formation. B. The prion paradigm of spreading indicates that $\alpha$-syn aggregates can be transferred from an "infected" cell (cell 1) to a "noninfected" cell (cell 2) through an unknown mechanism. When $\alpha$-syn fibrils arrive to the "non-infected" cell, they induce the misfolding of the endogenous native $\alpha$-syn protein, producing new aggregates that can be transferred to others "non-infected" cells, thus, propagating the disease.

Figure 2. Possible mechanisms of spreading of $\alpha$-syn aggregates. A. Adsorptive-mediated transcytosis of extracellular vesicles containing $\alpha$-syn aggregates: erythrocytes that contain a high concentration of aggregated $\alpha$-syn, can release extracellular vesicles enriched in $\alpha$-syn to the blood stream. These vesicles can cross the blood brain barrier (BBB) by adsorptive-mediated transcytosis and reach the brain. $\alpha$-Syn aggregates can be later internalized by the microglia. B. Exocytosis of $\alpha$-syn aggregates: $\alpha$-Syn aggregates can be derived to the MVBs and released to the medium in enriched exosomes (1) or inside other types of extracellular vesicles (2). It can be also directly released via a non-classical exocytosis mechanism (3) or via exophagy (4). Released $\alpha$-syn can be later internalized by neighboring cells. C. Internalization of extracellular $\alpha$-syn aggregated species: Monomeric, oligomeric and fibrillar species of aggregated $\alpha$-syn, can be internalized by the cell through endocytosis of different $\alpha$-syn-binding receptors at the cell surface or through direct endocytosis of $\alpha$-syn-containing exosomes. Once internalized, $\alpha$-syn is subjected to traffic through the endocytic pathway and finally delivered to the lysosomal compartment, from where it could escape by an unknown mechanism. D. Transfer of $\alpha$-syn via TNTs: lysosomes containing $\alpha$-syn aggregates 
can travel from one cell to the other inside TNTs. After arriving in the acceptor cell, $\alpha$-syn might escape from the donor cell's lysosomes and seed the aggregation of the native $\alpha$-syn protein. E. Trans-synaptic spreading of $\alpha$-syn: lysosomes containing $\alpha$-syn or naked $\alpha$-syn, can travel along the axon of neurons to reach the presynaptic terminals, from where it can be released in response to synaptic activity. Released $\alpha$ syn can be later internalized by the somatodendritic compartment of neighboring neurons. 


\begin{tabular}{|c|c|c|c|c|c|}
\hline $\begin{array}{l}\text { Experimental } \\
\text { approach }\end{array}$ & Animals & $\begin{array}{l}\text { Material } \\
\text { assayed }\end{array}$ & $\begin{array}{l}\text { Region of } \\
\text { interest }\end{array}$ & $\begin{array}{l}\text { Time } \\
\text { points }\end{array}$ & References \\
\hline \multirow[t]{2}{*}{$\begin{array}{l}\text { Engrafted } \\
\text { neurons on PD } \\
\text { brains }\end{array}$} & $\begin{array}{l}\text { Thy-1 } \alpha \text {-syn } \\
\text { transgenic } \\
\text { mice }\end{array}$ & $\begin{array}{l}\text { Mouse cortical } \\
\text { neuronal stem } \\
\text { cells }\end{array}$ & Hippocampus & 4 weeks & $\begin{array}{l}\text { Desplats et al., } \\
2009\end{array}$ \\
\hline & $\begin{array}{l}\text { Rats (WT) } \\
\text { injected with } \\
\text { AAV- } \alpha \text {-syn }\end{array}$ & $\begin{array}{l}\text { Rat embryonic } \\
\text { ventral } \\
\text { mesencephalic } \\
\text { neurons }\end{array}$ & Striatum & $\begin{array}{l}1 \text { week } \\
2 \text { weeks } \\
4 \text { weeks }\end{array}$ & $\begin{array}{l}\text { Angot et al., } \\
2012\end{array}$ \\
\hline \multirow{4}{*}{$\begin{array}{l}\text { Intracerebral } \\
\text { inoculation / } \\
\text { expression of } \\
\alpha \text {-syn }\end{array}$} & $\begin{array}{l}\text { C57BL6/C3H } \\
\text { mice (WT) }\end{array}$ & $\begin{array}{l}\text { Mouse } \alpha \text {-syn } \\
\text { fibrils }\end{array}$ & Striatum & $\begin{array}{l}30 \text { days } \\
90 \text { days } \\
180 \text { days }\end{array}$ & $\begin{array}{l}\text { Luk et al., } \\
2012 a\end{array}$ \\
\hline & $\begin{array}{l}\text { C57BL/6J } \\
\text { mice (WT) }\end{array}$ & $\begin{array}{l}\text { Human } \alpha \text {-syn } \\
\text { monomers, } \\
\text { oligomers and } \\
\text { fibrils }\end{array}$ & $\begin{array}{l}\text { Olfactory } \\
\text { bulb }\end{array}$ & $\begin{array}{l}20 \mathrm{~min} \\
1.5 \mathrm{~h} \\
3 \mathrm{~h} \\
12 \mathrm{~h} \\
72 \mathrm{~h}\end{array}$ & Rey et al., 2013 \\
\hline & $\begin{array}{l}\text { WT and } \\
\alpha \text {-syn null } \\
\text { mice, } \\
\text { monkeys }\end{array}$ & $\begin{array}{l}\alpha \text {-Syn extracts } \\
\text { from the PD } \\
\text { patients }\end{array}$ & $\begin{array}{l}\text { Substantia } \\
\text { nigra and } \\
\text { striatum }\end{array}$ & $\begin{array}{l}4 \text { weeks } \\
16 \text { weeks } \\
56-68 \\
\text { weeks }\end{array}$ & $\begin{array}{l}\text { Recasens et al., } \\
2014\end{array}$ \\
\hline & Rats (WT) & $\begin{array}{l}\text { Human } \alpha \text {-syn } \\
\text { oligomers, } \\
\text { fibrils and } \\
\text { ribbons. } \\
\text { AAV- } \alpha \text {-syn }\end{array}$ & $\begin{array}{l}\text { Substantia } \\
\text { nigra }\end{array}$ & $\begin{array}{l}20 \text { min } \\
7 \text { days } \\
120 \text { days }\end{array}$ & $\begin{array}{l}\text { Peelaerts et al., } \\
2015\end{array}$ \\
\hline \multirow[t]{3}{*}{$\begin{array}{l}\text { Peripheric } \\
\text { administration } \\
\text { of } \alpha \text {-syn }\end{array}$} & $\begin{array}{l}\text { WT and } \\
\alpha \text {-syn null } \\
\text { mice }\end{array}$ & $\begin{array}{l}\text { AAV-GFP } \\
\text { AAV- } \alpha-\text { syn }\end{array}$ & Vagus nerve & $\begin{array}{l}2 \text { weeks } \\
6 \text { weeks } \\
12 \text { weeks }\end{array}$ & $\begin{array}{l}\text { Helwig et al., } \\
2016\end{array}$ \\
\hline & $\begin{array}{l}\text { WT and } \\
\alpha \text {-syn } \\
\text { transgenic } \\
\text { mice }\end{array}$ & $\alpha$-Syn fibrils & $\begin{array}{l}\text { Upper hind } \\
\text { limb muscle }\end{array}$ & 16 weeks & $\begin{array}{l}\text { Sacino et al., } \\
2014\end{array}$ \\
\hline & $\begin{array}{l}\text { WT and } \\
\alpha \text {-syn } \\
\text { transgenic } \\
\text { mice }\end{array}$ & $\begin{array}{l}\text { Gut } \\
\text { microbiota } \\
\text { from PD } \\
\text { patients }\end{array}$ & & $\begin{array}{l}12-13 \\
\text { weeks and } \\
24-25 \\
\text { weeks }\end{array}$ & $\begin{array}{l}\text { Sampson et al., } \\
2016\end{array}$ \\
\hline
\end{tabular}

Table 1. Summary of in vivo studies representing the major milestones in the understanding of $\alpha$-syn prion-

like spreading properties. 


\begin{tabular}{|l|l|l|}
\hline a-Syn species & Transfer mechanism & References \\
\hline Monomers & Exocytosis and passive diffusion & $\begin{array}{l}\text { Lee et al., 2008; Fortin et al., 2004; } \\
\text { Martinez et al., 2007 } \\
\text { Fauré et al., 2006 } \\
\text { Ejlerskov et al., 2013 }\end{array}$ \\
\hline Oligomers & Autophagic & $\begin{array}{l}\text { Lee et al., 2008 } \\
\text { Fauré et al., 2006 } \\
\text { Lee et al., 2005/2008; Hansen et al., } \\
\text { 2011 } \\
\text { Rostami et al., 2017 }\end{array}$ \\
& $\begin{array}{l}\text { Exosomes } \\
\text { Endocytosis }\end{array}$ & $\begin{array}{l}\text { Fauré et al., 2006 } \\
\text { Lee et al., 2005/2008; Hansen et al., } \\
\text { 2011; Mao et al., 2016 } \\
\text { Abounit et al., 2016a }\end{array}$ \\
\hline Fibrils & TNTs & \\
& $\begin{array}{l}\text { Exosomes } \\
\text { Endocytosis } \\
\text { LG3 endocytosis } \\
\text { TNTs }\end{array}$ &
\end{tabular}

Table 2. Different mechanisms of transfer proposed to drive the spreading of $\alpha$-syn species. 


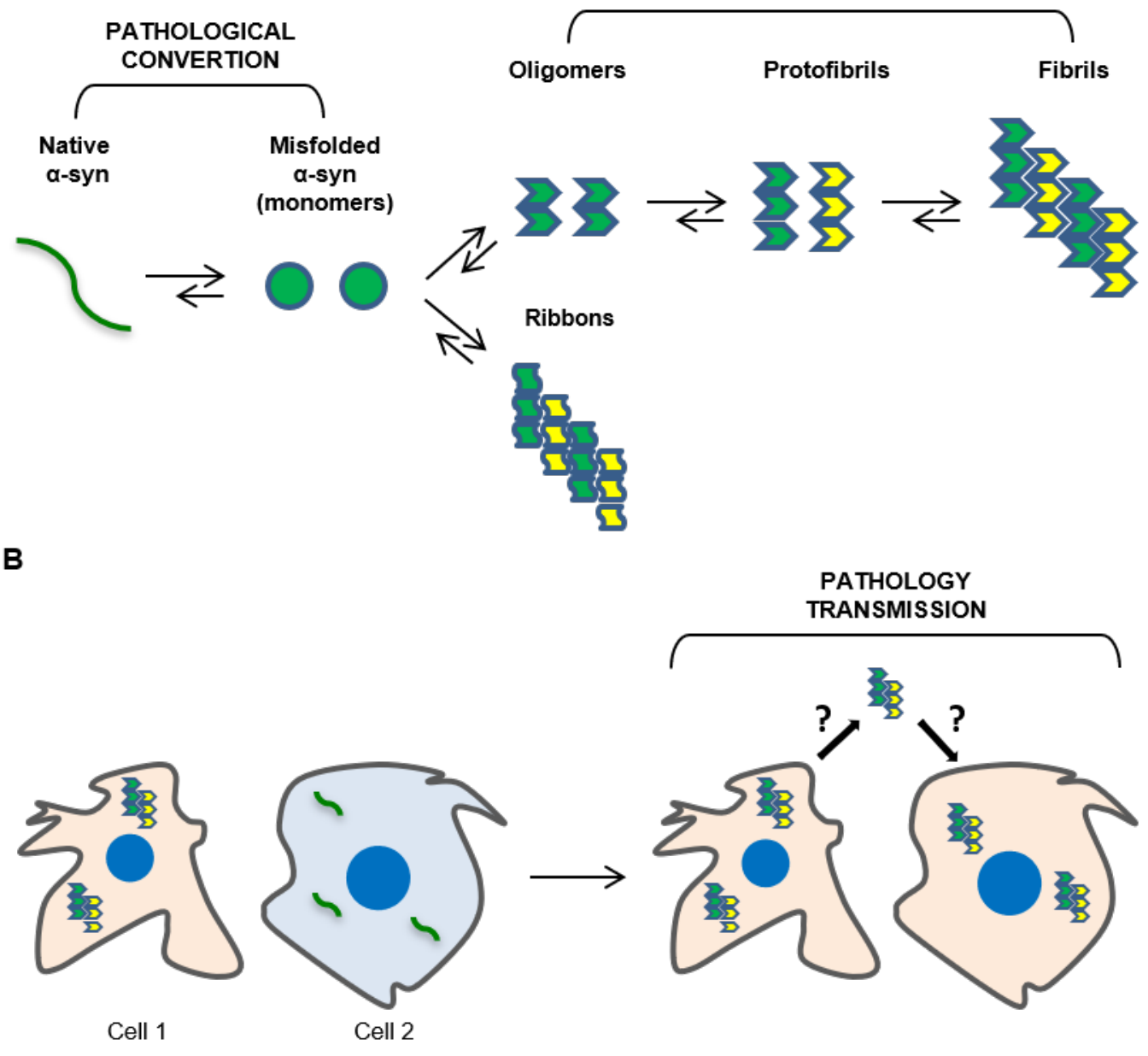




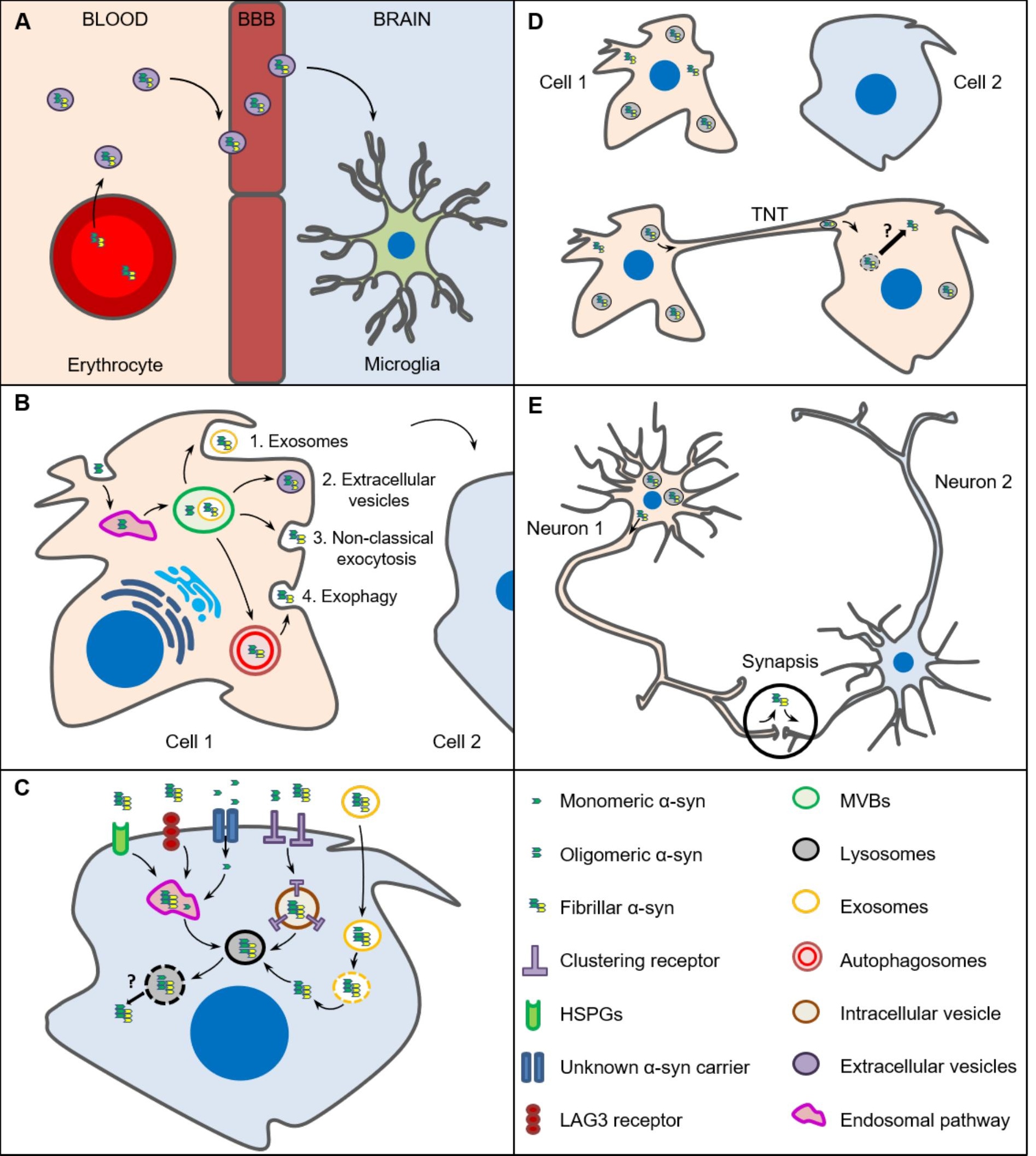

